University of Louisville

ThinkIR: The University of Louisville's Institutional Repository

Electronic Theses and Dissertations

1944

\title{
Under the blazing sun : a unit of work in social studies for the fourth grade.
}

Virginia H. Franklyn

University of Louisville

Follow this and additional works at: https://ir.library.louisville.edu/etd

Part of the Educational Methods Commons, and the Sociology of Culture Commons

\section{Recommended Citation}

Franklyn, Virginia H., "Under the blazing sun : a unit of work in social studies for the fourth grade." (1944). Electronic Theses and Dissertations. Paper 2044.

https://doi.org/10.18297/etd/2044

This Master's Thesis is brought to you for free and open access by ThinkIR: The University of Louisville's Institutional Repository. It has been accepted for inclusion in Electronic Theses and Dissertations by an authorized administrator of ThinkIR: The University of Louisville's Institutional Repository. This title appears here courtesy of the author, who has retained all other copyrights. For more information, please contact thinkir@louisville.edu. 


\title{
UNIVERSITY OF LOUISVILIE
}

Under the Blazing Sun

A Unit of Work in Social Studies

for the Fourth Grade

\author{
A Dissertation \\ Submitted to the Faculty \\ of the Graduate School of the University of Louisville \\ In Partial Fulfillment of the \\ Requirements for the Degree \\ of Master of Arts
}

Department of Education

by

Virginia H. Frankl, vn

Year

1944 
NANE OF STUDENT:

Virginia H. Franklyn

TITLE OF THESIS:

Under the Blazing Sun

A Unit of Work in Social Studies

for the Fourth Grade

APPROVED BY READING COMAITTEE COMPOSED OF THE

FOLLOWING MEMBERS:

W. C. Mallalieu

Hilda Threlkeld

J. J. Oppenheimer

NARE OF DIRECTOR:

J. J. Oppenheimer

DATE: Sept, 6,1944 
Under the Blazing Sun

A Unit of Work in Social Studies

for the Fourth Grade 
TABLE OF CONTENTS

CHAPTER

PAGE

I INTRODUCTION

A. Purpose

B. Incentive for Writing

C. Placement and Time

D. Evaluation of the Unit

E. objectives

II SOME CONCEPTS OF SOCIAL STUDIES AND THE NATURE OF THE UNIT

A. Old Ideas

B. Modern Concepts

c. Value of Unit

III A SUGGESTED OUTLINE FOR TEACHING THE UNIT OF SOCIAL STUDIES

A. Introduction

B. Overview

C. Themes

D. The Problem

E. Objectives

F. Specific Aims

G. Major Question

H. Methods of Approach

I. Content and Procedure

J. Pupil Activities

K. Culminating Activities

I. Evaluations

M. Vocabulary

N. References for the Pupil

0 . References for the Teacher

IV TEACHING THE UNIT IN SOCIAL STUDIES

A. Introduction

B. Overview

C. Approach 
D. Organization for Work

1. Geography Lesson

2. Reading Lesson

E. Correlation With Other Subjects

1. Arithmetic

2. Language

3. Reading

4. Science

F. Activities

1. Art

2. Construction

3. Dramatization

4. Preparation of Bedouin Food

G. Evaluation

IV TEACHING THE UNIT IN SOCIAL STUDIES (cont'd) SOURCE MATERIAL FOR THE TEACHER

A. Animals

B. Food

1. On the Desert

2. On the Oasis

C. Good Times

D. Homes

1. Tent

a. How Made

b. Furniture

c. Utensils

2. Dasis Town

E. Land of the Sahara Desert

1. Location

2. Rainfall

3. hovement of Sand

F. Occupations

1. Weaving

2. Sheep Raising

3. Shopkeepers

G. People

1. Appearance

2. Clothing

a. Women and girls

b. Men and boys 
H. Plants

I. Schools

J. Travel

1. Caravan

$\checkmark$ EVALUATION OF THE UNIT FROM THE STANDPOINT OF THE TEACHER

A. Achievements

B. Other Possibilities 
TABLE

PAGE

I RESPONSES TO AN INTERVIEW WITH TWENTY-FIVE FOURTH GRADE TEACHERS CONCERNING REFERENCES IN SOCIAI STUDIES' UNITS

II WEIGHTED TABLE OF THE RESPONSES OF INTERVIEW WITH TVENTY - FIVE FOURTH GRADE TEACHERS CONCERNING PREFERENCES IN SOCIAL STUDIES' UNITS

III AGE DISTRIBUTION OF FOURTH GRADE PUPILS IN VICTOR H. ENGELHARD SCHOOL, FEBRUARY, 1944

IV NUMBER OF TERMS SPENT BY PUPILS IN SCHOOL INCLUDING THE PRESENT TERM 
CHAPTER I

INTRODUCTION 


\section{CHAPTER I}

UNIT OF WORK - UNDER THE BLAZING SUN

INTRODUCTION

Introduction and Purpose. It is the purpose of this study to consider and construct a unit of work in social studies for the fourth grade. The investigation and study given to this problem are an outgrowth of sixteen years of teaching experience in the intermediate grades of the Louisville Public Schools. Seven of the sixteen years have been devoted to critic teaching.

A second aim of this unit is to teach ways of living on the Sahara Desert. Pupils of this age are interested in studying about other countries of the world. During the primary grades the children have been concerned with units based upon an environment which is more or less familiar to them. Recalling that one of our chief aims in teaching the social studies is to extend the child's experiences, we can now present types of people of other lands. The pupils have become famillar with the source of food, clothing, and shelter in their own country; now they find out how people of other countries adapt themselves to certain environments so that these same necessities may be secured. Thus they gain the ability in a simple way to reason from a certain type of environment to another resulting way of living. Ideas of the 
activites and habits of people of other lands are gained which form a valuable foundation for the history and geography study of the later grades. No attempt is made to teach the historical development of a people. The aim is rather to give a series of vivid pictures and impressions of the people in areas of their food, shelter, clothing and transportation.

The following spocific aims may be given in teaching the unit, Under the Blezing Sun.

1. To have children appreciate the fact that people living in different parts of the world must adapt their way of living to their particular environment. 2. To give pictures and impressions of the activities and habits of people in other lands. 3. To create an intelligent interest in other people. 4. To develop a feeling of frlendliness and sympathy for people of other lands.

5. To learn about children of other lands. 6. To contrast the food, clotining, shelter, and transportation of our own country. The plan of the unit includes a brief diseusgion of the underlying educational philosophy; changes in the teaching of social studies; and the construction of the unit. The latter consists of oontent material, teaching of the unit, tests, and evaluation of the study. 
The first incentive for writing of this unit came through the writer's experience as a oritic teacher. The student teachers' requests for a unit of work were evident. The critic teacher would give an outline of a unit of work to each student. The writer felt that a more detailed study would be more beneficial to the students. In fact, they requested a more complete study.

Twenty-five fourth grade teachers of the city of Louisville were interviewed by the writer. The following tables are the result of the interview. The teachers were not influenced by the writer. They were asked, "What country would you prefer written up as a unit of work? Which would be most helpful to you in your work as a fourth grade teacher?"

\section{Table I}

Responses to an Interview With Twenty-five Fourth Grade Teachers Concerning Preferences in Social Studies' Units.

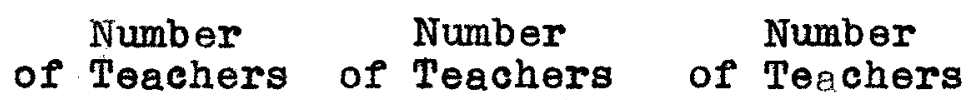

Country Pirst Choice Second Choice Third Choice Total

Sahara Desert Mexico

Switzerland

Brazil

Holland

Australia

Italy

China

Eskimo Land

Total

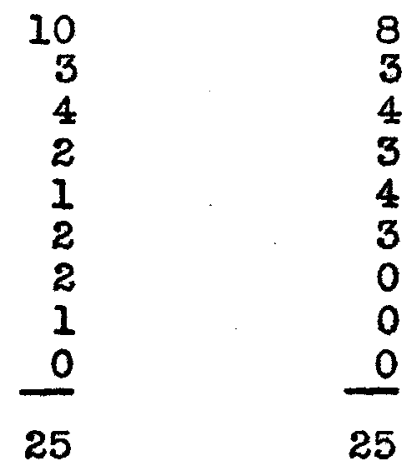

$\begin{array}{rrr}5 & 23 \\ 6 & 12 \\ 3 & 11 \\ 5 & 10 \\ 2 & 7 \\ 2 & 7 \\ 1 & 3 \\ 0 & 1 \\ 1 & 1 \\ 25 & 75\end{array}$


The following Table II has been weighted to show the importance of the unit chosen to be written up.

\section{TABLE II}

Weighted Table of the Responses of Interview with Twenty-five Fourth Grade Teachers Concerning Preferences in Soclal Studies' Units.

\begin{tabular}{|c|c|c|c|c|}
\hline lountry & $\begin{array}{c}\text { Number } \\
\text { of Teachers } \\
\text { Firgt Cholce }\end{array}$ & $\begin{array}{c}\text { Number } \\
\text { of Teachers } \\
\text { Second Cholce }\end{array}$ & $\begin{array}{c}\text { Number } \\
\text { of Teachers } \\
\text { Third Choice }\end{array}$ & Total \\
\hline & $\overline{X 3}$ & $x^{2}$ & $X I$ & \\
\hline Sahara Desert & 30 & 16 & 5 & 51 \\
\hline Switzerland & 12 & 8 & 3 & 23 \\
\hline Mexico & 9 & 6 & 6 & 21 \\
\hline Braz1l & 6 & 6 & 5 & 17 \\
\hline Australia & 6 & 6 & 2 & 14 \\
\hline Holland & 3 & 8 & 2 & 13 \\
\hline Italy & 6 & 0 & 1 & 7 \\
\hline China & 3 & 0 & 0 & 3 \\
\hline Eskimo Land & 0 & 0 & 1 & 1 \\
\hline Total & 75 & $\overline{50}$ & $\overline{25}$ & $1 \overline{50}$ \\
\hline
\end{tabular}

Table I gives the results as tabulated according to first, second, and third choices. In Table II each country has been weighted, flrst choloe counted as three, second choice two, abd third cholce one. The writer concluded the fact to be significant that of the twenty-five teachers with whom the interview was held, nearly one-half (I0 teachers) made Sahara Desert their first choice for study, nearly onethird ( 8 teachers) second choice, and one-fifth ( 5 teachers) third choice. It is interesting to note that in the total for Sahara Desert almost all the teachers (23) included this 
region in their choices for study.

In the weighted Table II the total 51 for Sahara Desert is one-third of the possible total of 150 proving that this unit is most desired by the Louisville teachers.

This unit was also selected because it is included in the course of study for the fourth grade in the Louisville Public Schools.

Our bullding is known as the Victor H. Engelhard School. It is located at 119 East Kentucky Street, Louisville, Kentucky. The enrollment in school varies from 600 to 650. The school is equipped with well chosen supplementery books for each room. These may be supplemented with books and pictures from the nearby Louisville Free Public Library and the Shelby Park Branch Library.

Thirty-three pupils, ranging in ages from eight to twelve were enrolled in the class carrying on this unit of work, which began February, 1944 and extended over an eight weeks' period. In the group were fifteen boys and elghteen girls. Table III shows the age distribution at the beginning of the unit.

\section{Table III}

Age Distribution of Fourth Grade Pupils in Victor H. Englehard Schøol February, 1944.

$\begin{array}{cccr}\text { Age } & \text { Boys } & \text { Girls } & \frac{\text { Total }}{8} \\ \frac{1}{1} & 8 & 10 & 18 \\ 9 & 4 & 4 & 8 \\ 10 & 1 & 2 & 3 \\ 11 & \frac{1}{15} & \frac{2}{18} & \frac{3}{33} \\ 12 & \frac{1}{15} & & \end{array}$


As shown by the table over fifty percent (18 pupils) were the average age (9 years) for the fourth grade. Table IV shows the number of terms the pupils have spent in school excluding kindergarten but including the present term.

\section{TABLE IV}

Number of Terms Spent by Pupils in School Including the Present Term

\begin{tabular}{cccc} 
Terms & Boys & Girls & Total \\
\cline { 2 - 4 } 7 & 9 & 12 & 21 \\
8 & 2 & 2 & 4 \\
9 & 3 & 2 & 5 \\
10 & 0 & 2 & 2 \\
11 & 1 & 0 & 1 \\
Total & $\frac{1}{15}$ & -18 & $\frac{1}{33}$
\end{tabular}

The table shows that nearly two-thirds of the class (21 pupils) have progressed consistently in their studies and have been in school the correot number of terms for their grade placement.

Twenty-seren of the pupils were of arerage mental ability, four were above average, and two were below. Twentyfour pupils came from homes representing moderate educational backgrounds and social attitudes. Financially they belonged to the middle class. The remaining nine members resided at the Baptist Orphans' Home and the Christian Orphans' Home. The latter included two boys and two girls, and the former four boys and one girl. 
In this school there is much freed om for the teacher and ample opportunity for initiative. The Louisville course of Study in Social Studies is merely to teach one half of the text in $4 B$ and the last half in $4 A$. The method of teaching in the book is only suggestive. It admits therefore, of opportunity to develop new ideas in social studies. The teacher is free to adapt the material in the book to any group of children, and to bring the work into harmony with their needs, interests, and abilities.

The writer belleves that the unit of work (1) is stimulated by the group to accomplish a worthwhile end, and (2) attracts to it a large number of experiences and various fields of knowledge. She hopes and believes that such a study as the unit provides will function in the life of the students and will manifest its value in a definite practical improvement in their attitude toward other peoples of the world. She also hopes that it will suggest many life-like problems and will open up various avenues of interest and knowledge. 


\section{CHAPTER II}

SOME CONCEPTS OF SOCIAL STUDIES AND THE NATURE OF THE UNIT 
SOME CONCEPTS OF SOCIAL STUDIES

AND THE NATURE OF THE UNIT

The social studies units are characteristic of the modern sohool. Normal children are forever active and curious; they are constantly exploring, investigating, making things, and playing. If these activities are directed toward some definite, worthwhile end, changes in habits, attitudes, and knowledge will be brought about. The social studies provide many activity situations or purposeful activities as a means of learning. Subject matter in social studies, in the modern conception, is important only as a means to an end.

The First World War gave new impetus to a movement which, for two decades previous to the outbreak of that great war, had been slowly gaining headway. The movement centered about the shifting of the emphasis in the teaching of geography from descriptive and place geography to relational and interpretative geography. Teachers of geography broke away from the old conventional pattern of teaching the subject and maps, slides, globes, and atlases assumed a new and more important aspect as visual aids. The stereotype approach which had developed during the nineteenth and early twentieth century receded to the background. During the years between the First and Second World Wars, the objectives of the teaching of geog- 
raphy as outlined by Moore and Wilcox ${ }^{1}$ were:

1. To develop an understanding of man's relation to his natural environment

2. To develop an abiding interest in the life of man as related to his environment

3. To give an understanding of the interdependence and responsibilities of peoples all over the world

4. To bring about an enrichment of social consciousness and a sympathetic understanding of our relation to all mankind

5. To teach man's chief needs and the arailable resources for meeting them

6. To give a knowledge of the problems of comnerce and communication that arise in supplying man's needs 7. To give geographic knowledge pertaining to common daily needs

8. To develop the ability to use geographic material such as maps, atlases, globes, books, charts, and graphs 9. To recognize the better ways of utilizing land and natural resources 10. To emphasize the relationship of scientific developments to commerce, industry, and social welfare

1 Moore, C.B., and Wilcox, L.A., Teaching of Geography, New York, American Book Company, 1932, p. 72. 
11. To impart geographic imformation necessary to the educational equipment of every normal American citizen 12. To emphasize the human aspects of geography 13. To give training in discovering some of the world's needs, differentiations as to values, and suggestions of means for meeting needs

14. To give some understanding of the more important activities in which men engage 15. To lay a sound foundation for related work at higher levels

16. To develop an understanding of geographic illusions 17. To cultivate an interest in present day affairs which will lead to wider reading

18. To emphasize the cultural aspects of geography in developing appreciation of natural elements, forces, scenery, customs, and folkway

19. To develop habits of applying geographic principles in the interpretations of current events Those who advocate the experience unit plan have a broad concept of the curriculum. Under this concept, the curriculum involves all elements of experience... . that is, everything the pupil does from the time he enters school until he leaves. To be of value, all experiences must be related and so arranged that the result will show a gradual 
growth from one experience to another. Harap interprets the unit as a coherent learning experience having a purpose which is meaningful to the pupil, which is accepted as his own, and which is closely related to a life situation. If the curriculum is made up of balanced, meaningful situations, all of the necessary fundamental processes wll function because the most successful ones will occur in the successive learning units. Among other representative and authoritative views the following can be mentioned:

"The social studies are the heart of the currioulum. - They must ${ }_{3}$ permeate and give significance to the whole school program."

"The social studies should be the core of the curriculum; - . the social studies more than anything else furnish elsolutely essential material and ideas."

"In no subject is the teacher of today charged with heavier responsibilities than in the teaching of social studies."

\footnotetext{
Harap, H., An Experience Curriculum, Washington, D.C., National Council of English Teachers, 1941, p: 105-109. 3

Tiegs, F.W., The Management of Learning in the Elementary Schools, New York, Longman, Green and Company, $1937, \frac{1}{\text { p.72. }}$ 4

Hughes, R. O. "Some Basic Considerations of Social Studies", Philadelphia, National Council for the Social Studies, Sixth Year Book, McKinley Publishing Company, 1936, p. 31-32. 5

California State Curriculum Commission, Teachers' Guide to Child Development in the Intermediate Grades, Sacramento, California State Department of Education, 1936, p. 14.
} 
"The various topics (of the social studies) may be called the articulating core of the curriculum. ${ }^{6}$

Michener and Long state that the principles that underIy the construction of a modern social studies unit can best be understood by an analysis of the extent to which units are able to meet the needs of society, to meet the needs of the child, and to preserve the values of scholarship and culture as represented by the subject matter of the social science. They further state that it has been generally agreed that social studies units must satisfy the criterion of social utility. D.V. Smith defines the ideal of social utility when he says, "The unit includes the larger movements of human history which explain the society in which the pupil lives, aiming at the development of a reasoning attitude toward the social world of today."

The elementary school in a democracy should provide lifelike situations with ample opportunity for practice in the right choices and actions; such a program, in school as In Iffe outside the school, leads into various subject matter fields, builds on knowledge already possessed, permits gener-

6

Stown, G. T., The Social Studies in the Primary Grades, New York, Lyons and Carnahan, I931, p. 1 .

"Michener, J.A., and Long, H.M., The Unit in the Sociel Studies, Cambridge, Massachusetts, Harvard University, 1940 , p. 13 .

8

Ibid. , p. 13. 
alization, and encourages practical applications. I.James Quillen contends that Democracy in the classroom has been extended by giving pupils opportunity to participate in proposing, planning, executing, and evaluating learning aotivities. Hffectiveness in reflective thinking has been developed by giving pupils practice in the reoognition and analysis of problems; the collection, evaluation, and organization of pertinent information; and the formulation, verification, and application of conclusions bearing on the problem being studied. By dealing with actual problems that arise, children learn to function as members of a social group and become consclous of each individual's place in the school, community, state, and nation.

Zoe Thrallis states that the six princlples for the selection and organization of materials for a geography curriculum may be summarized as follows:

1. Subject matter in geography should be selected in relation to a functioning knowledge of the interrelations existing between man and his natural environment. 2. Materials in geography should be so selected and so organized that, at each stage of development, a few important geographic units with clear cut major under-

9

Quillen, I.J. , Using a Resource Unit, Washington, D.C., National Education Association, 1942, p. 9. 
standings are treated thoroughly rather than many topies superficially.

3. All geographic materials should be oarefully graded on the basis of their relative difficulty. 4. In determining the emphasis to be placed upon the various major understandings selected as worth while, the principle of relative values should be recognized and applied in so far as such values can be determined. 5. Materials in geography should be so arranged that the relation of minor facts and understandings to major understandings is apparent in all cases. 6. The subject matter should be so selected and so organized, by means of careful study directions providing for specific but varied activities on the part of the learner, as to lead him toward mastery of the interrelations between the human pattern and the natural en10

vironment.

Dr. Carmon Ross, ${ }^{11}$ in his report of the committee on the social studies has made several noteworthy suggestions on the impact of war on the social studies. He and his committee did not subscribe to the wholesale denunciation of the present teaching of the social studies as inferred from the

10

Society's Committee on the Teaching of Geography, The Thirty-second Year Book, Bloomington, Illindis, Public School Publishing Company, 1933, p. 207. 11

Ross, C., "The Impact of War on the Social Studies," The Social Studies, (March, 1944), p. 116-120. 
recent study of one of our well known newspapers. Rather, they pointed out certain modifications and emphasis in the social studies which may assist youth to a better understanding of the causes of the war and post-war problems. While the committee did not subscribe to the "alleged" shortcomings in the teaching of the social studies, particularly American history, it did feel that there should be a total oversight of the results of the survey and the attendant criticisms. They suggest the following:

1. That a required program of social studies be prescribed, wherever possible for every year of the secondary school, and for all pupils, beginning with grade seven. It realizes that local conditions in some communities and state requirements in others make this impossible. Nerertheless, this does not justify any neglect of this program nor any considerable abridgement or deviation.

2. That to prescribe a social studies program for each year of the secondary school without vitalizing the program would be a grave error. To vitalize the social studies program requires an added emphasis by means of the following:

a. The consistent and organized use of a daily standard newspaper and current periodical literature.

12 Ibid., p. 117-118. 
b. The directed use of the radio--e.g. forum programs, public addresses, a few commentators; if possible, participation by pupils. c. The wider use of newer geographical sensory-visual aides - globes, new type maps, etc. d. The use of slide films and sound motion pictures, not as entertainment devices, but as eduoational aids. e. The more extensive use and interpretation of pictograms and other graphic aids.

f. The observance through properly-motivated and wellprepared programs of our significant holidays and birthdays of great national leaders. Such observances must aroid the trivial and common and instead must make use of pupils' creative writing ability and appeal to the dramatic and emotional. As soon as we can make as much out of some of these "holy days" as we do out of a "pep" football meeting, we may begin to derive some educational benefits from these obserrances.

g. The use of speakers who have a real message and who know whereof they speak. h. The use of music and art to illustrate and to emotionalize. Both subjects belong essentially to the social field. 
1. The wider use of debate and forum discussion groups

in sohool assemblies and in classrooms.

j. The interpretation of causes and effects.

3. That the new "air-age geography" be given an important place in the program of social studies. The cause and effect of geography in all great world movements should be stressed.

4. Cooperation among other fields should be developed in every school.

Many of the schools of the United States have offered study units on desert life simflar to that presented by the writer. Listed below are gome of the elementary schools which include such courses in their curriculum.

California, Berkley, The Public Schools, Volume I Social Studies, 1932

Idaho, Curriculum Guide, 1943

Indiana, Course of Study, 1933

Minnesota, Minneapolis Public Schools, 1943

Missour1, Gourses of Study for Elementary Grades, 1937

New York, Rural Elementary Curriculum Bulletin, Number Two,' 1936

North Dakota, 피mentary Courses of Study, 1928

South Dakota, Courses of Study Bulletin - Social Studies Number Five, 1932

The pupil experience type of unit is subscribed to by such authorities as Caswell and Campbell, Harap, and Hopkins. 
The following criteria as set up by the California curriculum 13

Commission are a fair expression of those endorsed by the writers named:

1. Is the activity closely related to the child's life

so as to lead him to want to carry it through?

2. Is it sufficiently within the range of acoomplish-

ment of the learner to insure a satisfactory degree

of success?

3. Is it so varied from the previous activity as to permit the child's all-round development?

4. Does it furnish opportunities for many kinds of endeavor?

5. Does the subject matter involved present major fields of human achievement?

6. Does the activity involve an extension of present insight and abilities?

7. Does it provide an opportunity for social contacts?

8. Will it lead into other profitable activities?

In evaluating the Unit of Social Studies the abore criteria have been used. This unit is so planned that the pupil has a part in choosing and planning what he will do. It provides opportunity for discovering significant relationships between our ways of living and other peoples of the

13

Caswell, H. L., and Campbell, D.S., Curriculum Development, New York, American Book Company, 1935, p. 434. 
world. The best of incentives for practicing and using the basic skills have been provided for. The teacher can discover how well the basic skills really function in such a study as described in chapter IV. The writer believes that it is challenging enough to provoke thought, that is organized around a vital center of interest, and that it promotes a spirit of cooperation and understanding among the students. Results of the teaching of the Unit of Social Studies have, in many respects, exceeded the writer's expectations. The pupils have accomplished many important purposes:

1. A better understanding of desert lands 2. A knowledge of the habits and customs of the inhabitants of other lands which will increase the spirit of international cooperation and goodwill both now and during the years after the war. 3. A better understanding of gepgraphy which will help the pupil to more readily comprehend the extent of this war.

4. A comprehension of the arailability of world resources and the problems of transportation and communication. 
CHAPTER III

A SUGGESTHD OUTLINE FOR TEACHING THIS UNIT 


\section{CHAPTER III}

A SUGGESTED OUTLINE FOR TEACHING THIS UNIT

A. Introduction. The writer presents this suggested outline for teaching the unit, Under the Blazing Sun, with the hope that it will prove beneficial to the teacher in her preparation for teaching desert life. The Social Study Unit has been flanned to give the pupil a better knowledge and understanding of other peoples of the world. The principles include an opportunity both for individual effort and group activity; give an experience which challenges interest, stimulates curiosity, requires problem solving, and provides opportunity for creative endeavor. The principles may be taught by means of discussion, dramatization, and investigation. Through a study of this unit, the pupil should be made conscious of the other peoples of the world.

B. Overview. The unit, Under the Blazing Sun, is to be a study of life on the Sahara Desert in North Africa. The development of an awareness of people in desert land and how they have adapted their living to their physical environment is to be emphasized. An understanding of how ways of living have been influenced by physical and climatic factors should be developed. The effect of modern communication and transportation facilities on ways of living, educational, cultural, 
and recreational opportunities should be studied.

Training in and for constructive membership in a democracy is an important aspect of the fourth grade social studies. Methods of attaoking social studies problems give training in direct and clear thinking so important in a democracy. Children can share in a thoughtful initiation of a unit.

c. Themes. The general themes may be stated as:

1. The necessity of man's adaptation to meet the requirements of living

2. Man's tendency to move from place to place in search of a higher standard of living

D. The Problem. The problems confronting the pupils were: How do the desert people live and why do they live as they do? The problems should evolve from the learning situation provided by the teacher, and should be the expression of a very real need on the part of the pupils themselves. As a rule, it should be proposed by one or more pupils of the class. The methods used in solving the problems will be controlled by the needs of the pupils and their past experiences in soclal studies. The types of methods may be analysis, experimentation, and investigation.

F. Objectives. The objectives of the teacher will be:

1. To show how people adapt their lives to climate and location

2. To lead children to appreclate advantages of living 
in a country like our own by contrasting our ways of living with those of the Bedouins.

3. To show our interdependence on other peoples.

4. To teach certain geographical facts.

5. To observe some of the effeots of a desert environment on plant, animal, and human life.

6. To encourage and develop desirable reading habits and skills.

7. To foster wholesome character traits as cooperation, respect for others, industry, and self-reliance.

8. To develop individual ability.

F. Specific Aims.

1. To give vivid pictures of the desert and desert life 2. To create an interest in, and friendiness toward other peoples

3. To show the effeot of the country on the life of the poople

4. To give some knowledge of the shelter, food, clothing, and transportation of the Bedouins

5. To show what causes a desert

6. To find out about the African deserts and the difficulties which our fighting forces encountered there. G. The Major question. The major question should follow the introduction of the problem through informal discussion. The discussion should stimulate thought and ouriosity as to 
how people of the desert live. Suggestions fron the pupils concerning the method of approach will aid in the solution of the problem. The major question for the unit, Under the Blazing Sun, may be, "Why do the people of the Sahara Desert Iive as they do?"

H. Methods of Approach. A few of the many effective methods of approach to the problem are listed here for the convenience of the teacher.

1. To be sure, the approach depends on the interest of the ohildren and the teacher. A brother of one of the pupils in the writer's class was a soldier that fought in the battle of North Africa. From time to time this pupil would tell the cless about his brother's letters. One child suggested that we take a make-believe trip to this "land of the blazing sun". Thus the name for this unit was oreated. All of the pupils were interested and thrilled to know that they were actually going to study about the country where our soldiers had recently won a victory. Naturally this pleased the teacher because a study of the Sahara Desert was to be included in their fourth grade curriculum. 2. Pictures of desert lands may be placed on the Bulletin board to arouse pupils' interest. A discussion of the pictures will create a desire to know more about these people who are able to live in a land where there 
is so little rainfall.

3. Stories of desert life may be read or told to the pupils.

4. After an imaginery visit with the Eskimos of Baffin Island, the children are usually anxious to return to warmer lands. Pictures again offer an incentive to locate the Equator and desert lands.

5. Children are always interested in pictures of shepherd life. Pictures of Bedouin shepherds mounted attractively and hung around the room make a natural introduction to the topio.

6. The study may begin from a study of clothing, where, after a study of wool in our own country, the children may be told of shepherd people who have always kept flocks of sheep or goats and who are great weavers. 7. A study of various types of shelter include among others the tent of the Bedouin and this may lead into a study of the desert lands. 8. Newspaper or magazine clippings of our fighting forces make an interesting approach to this unit. 9. A study of dates may be introductive to desert lands. 10. Plants such as the cactus may lead into further study of the Sahara.

11. A study of air transport routes may be of interest to pupils. 
The following general outline of content and procedure may serve as a guide in giving the pupil the fundamental knowledge necessary in answering the major question and similar questions.

I. Content and Procedure. The first step in the solution of the problem is the orderly arrangement of the subject matter to be taught.

1. Content Material

a, country, edge of desert, real desert, town

b. people, appearance, dress

c. homes, how made, furniture, utensils

d. Lood, how prepared, gardens

e. markets

f. transportation

g. animals

h. plants

i. Iife in an oasis town

j. ocoupation

j. schools

1. games

J. Pup11 Aativities. All of the previous observations, discussions, and reports should be followed with numerous activities. A few are suggested here:

1. Speoific

a. sandtable desert scene

b. individual desert scene made in a box

c. model desert animals

d. make a large picture map of Sahara Desert

e. make a product map of Sahara Desert

f. weave a rug

8. prepare Bedouin food

h. write letters of invitation

i. original stories and riddles

j. play Bedouin games

2. General

a. oral discussions on special topics

b. creative work, art, construction, drawing, painting, modeling 
3. Correlation with other subjects
a. arithmetic
b. langauge
c. reading
d. soience

K. Culminating Activities. Many culminating activities present themselves during the study of desert life. Among those that pupils are interested in may be mentioned:

1. Dramatization of desert Iife

2. Preparation of a radio program

3. Make a class booklet to be used by future classes or by another fourth grade

4. Prepare an exhibit of desert products

5. Write a source book of desert life for pupils

6. Prepare a detailed bibliography of desert stories.

L. Braluation. Finally the teacher will need definite plans for evaluating the unit, and it is hoped that the following suggestions will assist her in the undertaking. Some of those for use in measurement are:

1. Has the pupil gained from the study a new attitude toward and appreciation of other peoples of the world? 2. Has he developed an increased ability in locating material in solving a problem?

3. Has he aoquired skill in selecting and handing materials?

4. Has he leamed to cooperate with other members of the class? 
5. Has he developed his vocabulary?

6. Has he shared his knowledge and experiences with his group?

7. Has he developed better habits, attitudes, and skills

in his study?

8. Has he experienced various sources of learning possible through the use of all sense organs? 9. Has he been lead into new activities and interests which will provide opportunity for continued growth of the child?

10. Has he had an opportunity for firgthand experiences through use of materials adapted to reading abilities represented?

11. Has he done oritical thinking as evidenced by recognition of problems, by more thoughtful and penetrating consideration, and by growth in ability to plan, execute, and evaluate on higher levels?

12. Has he correlated several fields of human knowledge such as geography, reading, English, science, music, art, and construction?

13. Has he had extensive opportunity for the use of the major skills such as reading, writing, spelling, and number relations?

14. Has he had more meaningful and effective drill in the content subjects? 
Tests may be constructed by the teacher to determine results as outlined above. Objective tests may be devised by the teacher. Some of these may be, the true-false type, multiple choice type, the completion type, the matching type, and the picture type.

By the use of these tests the teacher may determine the grpwth in the child's understanding of desert life; his increased ability in handing materials; in the acquisition of an adequate vocabulary; and in his ability to do critical thinking.

M. Vocabulary. A definition of some of the terms used in this study seems to be an essential part in the teaching of the unit, and is herein provided for convenience of both teacher and student:

1. Antelape - a deer like animal

2. Bedouins - a tribe of people who live in the desert

3. Camel - a large animal with a hump used in the desert regions to carry burdens and to ride upon. 4. Caravan - a line of people and camels moving across the desert

5. Compass - an instrument for determining directions by means of a magnetized needle or bar which indicates north and south

6. dagger - a short weapon for stabbing used by the Bedouins to defend themselves

7. Date - the oblong, single-seeded, sweet fruit of a palm tree of Northern Africa 
8. Desert - a barren piece of land where there are not much water and trees

9. Donkey - an animal used by the Bedouins for traveling 10. Dune - a heap of drifted sand

11. Goatskin Bag - a bag made of goatskin used to carry water or milk

12. Headcloth - a cloth wrapped around the Bedouin head for protection from the sun 13. Herd - a number of beasts

14. Herdsmen - Men who own, keep, or tend a herd or herds

15. Irrigate - to give land or artificial water supply 16. Koran - Mohamnedan Bible; Holy Book

17. Litter - big baskets on top of camel in which the women and children ride

18. Millet - a annual grass raised for its grain or cut for hay

19. Mimosas - any of many trees, shrubs, and herbs of warm regions, with cluster of white or pink flowers 20. Mosque - a Mohammedan Temple

21. Nomads - wanderers of the desert

22. Oasis - a place where there is water in the desert 23. Ostrich - a swift-footed African bird, the largest existing bird, weighing 300 pounds; its wings are useless for flight 
24. Pancakes - a griddle-cake

25. Robe - an outer dress of a flowing style; dress of Bedouing

26. Saddle - a seat for a rider on a horse's back;

part of a harness

27. Sandstorm - a wind storm carrying sand

28. Shawl - a square or oblong garment used to cover

the neck and shoulders

29. Sheik - a leader of a tribe of Bedouins

30. Tent - a shelter of skins or cloth stretched over

a pole or poles

31. Tribe - a division or group composed of individuals having some common characteristics

32. Turban - a headdress of Bedouin men and women

33. Wanderers - people who wander over the desert

34. Weare - to unite, as threads, so as to form a cloth 35. Wheat - a well known cereal grain, next to rice the most used of any grain

N. References for the Pupils:

Atwood, W.W., and Thomas, H.G., Home Life in Far Away Lands, New York, Ginn end Company, I933, $\frac{110}{\text { p. } 54-7 \bar{~}}$

The information given in this book is especially good

for oral reports on special topics.

Carpenter, F., Our Neighbors Near and Far, New York, American Book Com any, 1938 , p. 76-106.

This book contains much valuable information on desert life. 
Carpenter, F., our Little Friends of the Arabian Desert, New York, Amerioan Book Company, $\overline{1934 .}$

This is an excellent book for the library table.

Carpenter, F.G., Around the World With the Children, New York, American Book Company, 1921.

Although this is an old book, it contains good descriptions of desert lands.

Comfort, M.H., Peter and Nancy in Africa, New York, Beckley Cardy Company, 1935.

This book would be better for the first group in reading.

It deals with the travel of two children in Africa.

Crabtree, E.K., Walker, L.C., and Cenfield, D., Under the Sun, New York, University Publishing Eompany, 1941, p. 93-161.

This book can be read by all groups in reading. It is unusually well written for children.

English, M., and Alexander, T., Wide Windows, New York,

Johnson Publishing Company, I935, p. 55-63.

This is a story of Ali's trip to his grandfather's

home on an oasis. It can be read by all groups in reading.

Freeman, F.M., and Johnson, H.M., Child-Story Readers, New

York, Lyons and Carnahan Publishing Company, 1938, p. 119-122.

This is a short account of desert homes.

Hardy, M., Best Stories, New York, Wheeler Publishing Company, 1934, p. 160-166, p. 230-237.

The first story tells about how the Arabians use milk. The second story is about a little camel driver's experience in a sandstorm. 
Harris, J.M., Visits Here and There, New York, Houghton

Mifflin Company, 1935, p. 121-126, p. 130-134.

This material is best adapted for slow readers. It is

a story of moving day on the desert.

McConnell, W. R., Living in Different Lands, New York, Rand McNaliy and Corapany, $19 \overline{38, ~ p . ~ 68-89 . ~}$

This is the text book for the fourth grade in the city of Louisville. It is very helpful and suggestive.

Palmer, W.B., Abdul, New York, Henry Holt and Company, 1928. This makes a good book for the teacher to read to the class. It is the story of an Arabian boy. The boys like the book especially well.

Petersham, M., and M., The Story Book of Houses, Chicago, Illinois, The John C. Winston Company, 1933, p. 14-15.

The book is especially good for colored pictures of desert homes.

Petersham, M., and M., The Story Book of Transportation, Chicago, Illinois, The John C. Winston Company, 1933, p.14-15.

This story describes desert travel and gives good illustrations of how the camel help the Bedouins.

Ratzesberger, A., Camel Bells, Chicago, Illinois, Albert Whitman Company, 1934 .

A very good book for the library table. The 1llustrations are well done.

Simpson, M. E*, and Adams, M.A., Growth in Bnglish, New York, Newson and Company, 1934, This book is especially helpful in language work. It 
contains a unit of work in sentences and paragraphing on desert iffe.

Smith, N.B., Near and Far, New York, Silver Burdett Company, 1940 , p. $108-146$.

The pupils like the stories about the stars in this book. It also includes the plan for a desert lunch.

Smith, N.B., and Bayme, S.F., Distant Doorways, New York, Silver Burdett Company, 1940, p. 66-133.

These stories are unusually well written for reading lessons. They are informational as well as entertaining. Smith, N.B., and Bennett, E.H., About Camels, New York, Silver Burdett Company, 1937.

This material is best suited for slow readers. It contains some very good illustrations.

Wilson, H.E., Wilson, F.H., and Hrb, B.P., Ways of Living

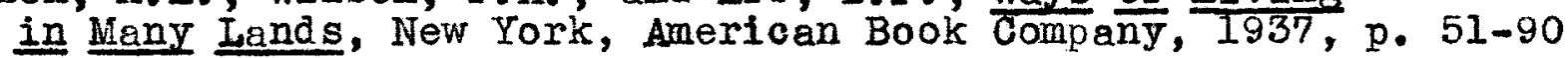

This book contains the best information about the desert.

It is adapted to fourth grade pupils, and it is told in an interesting way. It also contains many good suggestions on how to teach about desert lands.

0. References for the Teacher. All of the references for the pupils will prove beneficial as well as instructive to the teacher.

Fitzgerald, W., Africe, New York, E.P.Dutton and Company, 1939.

Harrison, P., Arab at Home, New York, T.Y.Crowell Company, 1924. 
Maisel, A.0., Africa, New York, Buell, Sloan and Pearce, 1943. Seabrook, W.B., Adventures in Arabia, New York, Harcourt Brace, and Company, 1927.

Wells, C., Introducing Africa, New York, G.P. Putnam's Sons, 1944.

Woolbert, R.G., Look at Africa, New York, Foreign Policy Association, 1943 .

\section{Magazines}

New Republic, January 31, 1944, p. 110-157.

National Gepgraphic 84: July, 1943, p.1-31.

Saturday Evening Post, $216-(p .14,15)$ July, 1943., August 21, 1943, p. 23, 225 .

\section{Government Document}

Pocket Guide to North Africg, Washington, D.C. War and Navy Departments, 1943. 


\section{CHAPTER IV}

TEACEING THE UNIT IN SOCIAL STUDIES 


\section{CHPATER IV \\ TEACHING THE UNIT IN SOCIAL STUDIES}

A. Introduction. The Social Studies Unit has been planned to give the student a better knowledge and understanding of other peoples of the world. The unit is so planned that the activity is stimulated by the group or one of the group to accomplish a worth-while end. It attracts or draws to it a large number of experiences and various fields of knowledge. It is felt by the writer that any large activity which is started for the achievement of a real purpose will lead into many life-like problems and will open up varfous fields of interest and knowledge. One of the big objectives of the social studies is to bring about an adjustment of human personalities and the making of better citizens. The writer feels that the objective was accomplished to a large degree in the teaching of this unit of work. The writer spent eight weeks in teaching the unit, Under the Blazing Sun, to a class of Fourth Grade pupils at the Victor H. Engelhard School. She took the children as they were and helped them to adjust themselves to their environment by giving them a better understanding of what is going on in the world about them and some appreciation of how the desert people live. In doing this the teacher 
felt that she was helping them to organize their world and to orlent themselves in it. She was helping them to interpret the experiences they have had and provided opportunity for extending their experiences.

Before presenting the materials she studied carefully the outlines of the unit, did a great amount of reading on the desert lands and gained a clear conception of the attainments she hoped to see realized.

The problem was to study desert life on the Sahara and find out why the Bedouins live as they do. The working of the problem involved a study of the available material on the desert. The unit developed the power of observation. The pupils were trained through the unit to look for sources, causes, effects, and significant detalls.

The unit established right attitudes. Right attitudes developed as children worked together in groups - constructing, planning, suggesting, and evaluating one another's suggestions. In working on the study, the children saw the need of cooperation and self-control and soon learned that each child's responsibility contributed to the general success of the undertaking. When he contributes his part toward a definite end, he feels that he is a worthy citizen of a most important group and he learns that a good citizen is ever conscious of the rights of others. A fine spirit of appreeiation and good will was built up when the pupils studied 
desert life, for they learned to understand others and their work, and how other poople contribute to their comfort, even those in far away lands who supply us with food, clothing, and pleasure.

The unit stimulated thinking and problem solving. To solve any problems that arise in connection with life experiences, one needs related knowledge. The writer feels that the pupils have gained a great amount of related knowledge during the study of the unit.

Activities and culminating activities engaged in during the study will be recorded and explained later in this chapter.

The African deserts with their picturesque landscape and native life have long been a fascineting subject. Now that they have been a scene of battles between the armed forces of the United Nations and the armies of the Axis powers, they have taken on a new interest.

B. Overview. The pupils had a very definite part in the planning of this unit. They suggested, Under the Blazing Sun, as an appropriate name for our study. They had noticed the glare of the sun as shown by the coloring in many pictures of desert life. The word "blazing" had been discussed during a previous reading lesson. The pupils planned an imaginary trip by plane to the Sahara Desert. They wanted to find out all they could about how these desert people live and why they live as they do. They decided to find out how our armed 
forces were able to stand life on a desert. The pupils planned to make a blbllography of all the desert material in our room, as well as any outside material they could get from the library. One pupil suggested working in groups on special topics in solving our problems on desert life. This idea was heartily received by all the class. It was agreed to read for two weeks all the material that was available on Sahara Desert. They thought this would give them a better opportunity to choose the topic in which they were most interested. The pupils were particularly interested in planning for some oulminating activity in which they could tell other classes what they had learned at the end of the study. The more artistic children were very anxious to plan for a desert sandtable scene, as well as for drawings and paintings of desert life.

The teacher told the pupils that our language, reading, and geography lessons would center about desert life. "Perhaps we will use an arithmetic or science period if the ocoasion arrives. At the end of our study we want to be able to answer any questions that arise in your minds, in desert life. We want to know why these people I1ve as they do and how their lives are different from ours."

C. Approach. After the pupils decided on an imaginary trip to the Sahara Desert of North Africa many questions began 
to be raised as to how they could get there; what do we want to find out when we get there; and what kind of clothing would be best to take. The pupils docided to make a list of questions on the board to guide us in our study. The following questions were suggested:

1. What is the Sahara Desert like?

2. What kind of people live there?

3. How are their homes made?

4. Do they eat many kinds of food?

5. What animals do they raise?

6. How do the desert people dress?

7. What is an oasis?

8. What is a caravan?

9. Why do these people move so often?

10. What kind of weather do we find on the desert?

11. What makes a desert?

12. What did our soldiers have to know about desert fighting?

13. How did the desert affect our soldiers?

14. What do we get from the desert?

15. What do we these people from our country?

16. What kind of sohools do they have?

17. What do they do for a good time?

18. How do they travel? 
The pupils requested a copy of these questions so that they might keep them in their geography notebooks. The writer duplicated these questions and each child pasted them in his notebook.

The pupils began in earnest to make a bibliography of all the material available in our room on the desert. They knew the meaning of bibliography from their previous study in Pioneer Iife. The teacher and pupils provided the pictures of Bedouins for the bulletin board. Many library books, newspaper clippings, letters, and other pictures were brought in from time to time as the unit progressed. The pictures of desert life furnished the necessary background or setting which led the children to see how the desert people are affeoted by their environment.

D. Organization for Work. The pupils decided that they would like to take their imaginary trip to desert lands by airplane. Possible routes were traced on the wall maps as well as individual maps in their own text book. Since they decided to go by plane, the pupils realized that their baggage would have to be limited. After studying some pictures, the children planned to take their coolest clothing, as well as a coat or sweater to wear at night on the desert. Most of the pupils were as excited as if they were actually going on a trip. The morning conversations centered around our imaginary trip. Such comments as, "Will we make the trip all in

14

McConnell, W.R., Living in Different Lands, New York, Rand McNally and Company, $1938, p \div 6 \frac{1799}{9}$ 
one day?" or "Is the plane large enough to take us all?"; still others asked, "I believe I would feel safer on an ocean liner. May I go by boat?"

After their safe arrival in the desert of North Africa, the pupild began to feel the need for reading and studying their geography books so that they would enjoy their trip and know more about what they were going to see. Up to this perlod plcture study had been sufficient to satisfy their needs. But now their questions could not be answered to their complete satisfaction by picture study alone. The reading material in their text books, library books, and readers were utilized by every pupil. After several periods of independent reading and gathering of information, the children suggested reorganizing their questions under main topics. "I believe we can read with more understanding if the topics were larger and the questions were better organized," suggested one pupil. All the children agreed that this was something for us to think about. The teacher called the class together and they discussed the possibilities of grouping their questions under main topics. The writer was well pleased with the progress the pupils had made thus far. She had already realized one of her main purposes of teaching this unit. The pupils had actually felt the need of evaluating the questions and sharing their thoughts with the group. 
The following topics were suggested:

1. Country

2. People

3. Homes

4. Food

5. Travel

6. Occupations

7. Plants

8. Animals

9. Schools

10. Games

Other comments were not uncommon after the topies were decided upon, such as, "I believe I have a better idea of what to read for than I had before;" or "I am interested in finding out more about the homes of the people".

A surprising amount of material was brought in even after the completion of our visit to desert lands, which showed the continuity of the pupils' interest.

In a brief introductory talk to the children, the teacher explained that their geographies would help them to understand why the homes, dress, and ways of living of many peoples were different from ours. She then had the children locate on the maps in the text and on the board map the Sahara Desert. The physical maps in their text were used; that of 15 the globe, also, an outline map of Africa which the teacher

15

Ibld., p. 69. 
had drawn on the board before the lesson. A light brown oolor was used on the board map to represent the desert lands. The teacher supplemented the pictures in the text with a number that showed the character of desert lands and what man is doing in these lands. It was the initial step in the development of the idea of man's adjustment to his natural environment. In examining the physical maps the children noticed the flatness of the land.

During the discussion periods the children would share with the group the material they had read and studied. One of the first questions brought before the group was, "What is a desert?" Several pupils were ready with an answer from their reading.

"A desert is a place where few people live."

"A desert is a hot, ary place."

"A desert is a place where we do not find much water." Many other definitions of a desert were given by the class. The books for children of this age do not include any of the soientific reasons for a desert. The teacher must use her own fudgment as to how much of the causes of desert her pupils are able to grasp. The teacher in this situation deemed it advisable to explain to the pupils the reasons for deserts. She told tham that when low land, so that the rain clouds from the ocean are out off usually become desert. The pupils of this age were able to understand that statement. The writer also explained about the amount of rainfall. She 
told the group that a desert is a dry region, where the annual rainfall is less than ten inches. She explained that ten inches means that if all the rain and melted snow that fell in a certain place in an entire year remained upon the top of the ground without running off or eraporating, the total depth of the water at the end of the year would be ten inches. This particular group had previously studied in their science lessons, water, evaporation, and rainfall. They had carried out experiments in evaporation, so they had no great difficulty in comprehending the explanation given by the teacher.

After discussing, "What is a desert?", the teacher proceeded.

Teacher: "You have a general idea of a desert, but your geography will tell you more. Let's all turn to page 74."

The children found the paragraph callod, "What is a desert," and one pupil read it orally.

Teacher: "Who will read what it tells us under 'Figure 70'g" (The pupil read it very well.) "I would like for some one to read the second paragraph on page 70 which tells us more of how the people live."

Child read.

Child: "That reminds me of another story I read during the seatwork period. I believe it was in the Wide Windows Book." Teacher: "Yes, there are many interesting stories about 
these desert people in our readers, and I am oertain that you will find the same information in some of the stories." The teacher wrote on the board "Figure 75" and had a child find the plcture and tell in his own words what it showed.

The children gave "sheik" as a name of a caravan leador and referred to the story they had previously read about a sheik. "Robbers in the right," in Ways of Living.

Teacher: "What is a caravan?" You will find the answer in your book."

One child read orally the paragraph, "What is a caravan," on page 75 .

The teacher showed the pupils a large colored picture of a caravan traveling across the desert. After studying the picture carefully, the children were eager to discuss what they had seen.

Child: "I don't see how the desert people can be so patient about waiting for water."

Teacher: "That is one lesson we could learn from them. Don't you think so?"

Child: "Yes, I agree with you, but sometimes it is hard for me to do. The camel is certainly a good animal for the desert. He can go for many days without water."

Teacher: "There are dangers in the desert as well as in our country. Have you read about any in your readings?" 
Child: "Yes, robbers sometimes steal the Bedouin's camels or other animals."

Child: "Sand storms are dangerous for animals and people."

Child: "Sometimes the camels are frightened by strange horses."

The teacher wrote on the board "Figure 76". A child read the statements under the picture. "Read page 76 and see if you can find out anything that you didn't know about riding on a camel."

Child: "The leader makes the camel kneel when you get on so you don't have to use a ladder."

Child: "A camel swings from side to side when he walks." Teacher: "Some books call the camel the 'Ship of the Desert'. I want you to remember this and in your reading perhaps you will come across some good reasons for this name." Child: "I would like to make a special report on the camel. He certainly is an interesting animal. Last year when I was at the circus I saw a cream colored camel. I never had any idea that he could be so useful."

In their discussion the children supplemented the materfal of the geography text with information from other sources. Teacher: "Let's look at 'Figure 78'."

one child read the statements and answered the question asked. The word "ripples" was explained by the teacher as well 
as the word "dune".

Teacher: "I have a picture I found in the paper which shows two soldiers going to war in North Africa. What does it tell youp"

Child: "The soldiers have their faces covered to protect them from the sand."

Child: "One is wearing goggles to protect his eyes from the blazing sun."

Teacher: "I am glad to hear you using that expression "blazing sun", because we are calling our study, "Under the Blazing sun".

other figures in that text were studied in the same manner. The relationship between the work of the reading period and that of other subjects of the curriculum is reciprocal. The above lesson is an example of how content subjects contribute to greater proficiency in reading.

Below is given a afferent type lesson illustrating. another way in which reading was used during this period. This lesson was given from Ways of Living in Many Lands. Aims of the Lesson

1. To answer some of their questions about desert life.

2. To read with purpose and understanding.

3. To find material which relates to the subject they are interested in.

4. To increase reading skills and abilities.

\section{6}

Wilson, H. F., and Others, Ways of Living in Many Lands, New York, American Book Company, i97, p. 51-57. 
5. To stimulate interest in desert life and people.

6. The correct use of index, glossary and dictionary whenever possible.

Approach

The previous day a story was read about desert life and people. Then a picture was given to each child to observe and discuss. This introduction to desert life was followed by a class discussion of the desert and what we wanted to learn about the people there. In this reading lesson we were looking for the answers to some of our questions.

Methods

Seat Work Period - During this period the pupils read the lesson silently and answered questions which were on the board. These questions were to motivate more comprehensive reading.

1. Name the important parts of the story.

2. What is a desert?

3. What do camels do during a sandstorm?

4. Why did Omar place his robe on a bush?

5. How does the oamel help the Bedouins?

6 . How do the Bedouins dress?

7. Be able to describe a Bedouin supper.

The children were called to the group and the class discussed the reading lesson and questions. Some of the questions were proved by reading orally the answers found in the book. In this way oral reading was motivated. Since the first discussion a chart had bien posted with the topics we wanted to learn about on it.

$\begin{array}{lll}\text { Country } & \text { Climate } & \text { Food } \\ \text { Animal } & \text { clothing } & \text { Travel }\end{array}$

This lesson was concluded by a summary of what we had learned and what things we wanted to watch for in our reading.

Assignment

In our work on this unit we want to collect as much information as possible on our, topics. This information is to be used in writing compositions on phases 
of desert life and oustoms. On the library table there are books about the desert. In your spare

time read to learn more about your topics.

Other stories were handled with the same procedure.

Other suggested outlines for silent reading are given below. These questions may be placed on the board before the lesson.

1. Name the main scenes in the story.

2. Describe a Bedouin meal.

3. Describe a visit to an oasis.

4. Disouss a visit to a Bedouin market.

5. Do you think the story has a good name? If so, why?

If not, suggest another name.

6. Plok out all the words that pertain to desert life.

What does each mean? Use each word in a sentence.

7. What did you learn about Bedouins from this story?

8. How can we help the Bedouins? How can they help us?

9. Write a letter to your best friend and tell him the

part of the story you liked best.

10. Pick out the most exciting part.

11. What fangers do you think our Armed Forces had to face while in North Afrlca?

After two weeks of reading, studying, each pupil had chosen his topic for a speoial report. Since the group had decided on ten main topics, that meant that a committee of three or four pupils was formed to study each topio. The teacher made a large chart upon which were printed the ten 
topics. During the next two weeks the ohildren worked hard on their topics. Many pupils made drawings to illustrate their oral reports to the group. As the topics were discussed, the teacher would check on the chart the subject being discussed. After each report, the children asked each other intelligent questions concerning their topic. In some instances the pupils would refer to maps, readers, or pictures to prove the facts they had given to the class. A spirit of friendiness and cooperation prevailed throughout the entire time devoted to oral reports.

D. Corrolation With other Subjects.

1. Arithmetic

One of the main objectives in the teaching of arithmetic is the development of the child's ability to solve the problems wh1ch he meets both in and out of the classroom. The teacher has utilized in every possible way the activities of the school as a source of problems. She has kept in mind that the best way to organize problems is in some social setting, Below are given some examples of classroom activities that provided problems of social setting.

a. Dramatization.

Problems wexe used based on the cost of Uncle Sam's costume such as:

(1) Blue cambric cost 35 cents a yard. If we buy 
3 yards, how much will the material cost?

(2) If I give the clerk a $\$ 5.00 \mathrm{bill}$, how much change should I receive? If I give her a $\$ 10.00$ bill how much change should I receive?

(3) I need li yards of white cambric. White cambric costs 30 cents a yard. How much will the material cost? If I give the clerk a dollar, how much change should I receive?

(4) Blue stars cost 25 cents a box. I am going to buy two boxes of stars. How much change should I receive from a dollar?

(5) How much would the entire bill be? What change should I receive from $\$ 5.00$ ?

b. Planning the desert party.

Numerous problems presented themselves in planning for our desert lunch. The problems were worked out during our arithmetio period. The pupils felt a definite need for greater skill in the four fundamentals processes of Arithmetic. The pupils formulated problems of their own. Many times they would exohange problems with their olassmates and solve each other's examples. Such problems as the following presented themselves:

(I) If there are 33 children in the room and each child is asked to bring 6 cents for the party, how much 
money will there be?

(2) If bread cost 12 cents per loaf, how much will five loaves cost?

(3) Mary earned 75 cents. She brought 35 cents to school for out party. How much money did she have left?

(4) Our party will cost $\$ 5.00$. We have $\$ 3.75$. How much more do we need?

(5) We need 33 sandwiches. Betty has made 17, how many more sandwiohes does she have to make?

(6) Butter cost 50 cents per pound. We need $1 \frac{1}{2}$ pounds, how much will that cost?

(7) Cookies are 30 cents a dozen. We need $3 \frac{1}{2}$ dozen, how much will they cost? If I pay with a $\$ 5.00 \mathrm{bill}$, how much change will I receive?

(8) Dates cost 38 cents per pound, we noed 2 pounds. How much will the dates cost?

(9) I bought four loaves of bread at 12 cents per loaf, 1 pound of dates at 38 cents per pound, 1 pound of butter at 50 cents a pound, and 1 pound of cheese at 30 cents a pound. What was the total costs

(10) We need 35 bottles of milk. Milk costs 5 cents per bottle (half pints). How much will all the milk cost? How much ohange should I get from a $\$ 2.00$ bill? 


\section{Language}

The dramatization given later in this chapter gives a good example of the language work accomplished in this unit. The pupils prepared their oral reports on their special topics during the language periods. The teacher met with each group individually before these oral reports were presented to the class. The members of the group evaluated the material and struck out any duplicate material given. After the oral talks were given, three groups decided to get together and write the dramatization.

a. Letter Writing

An invitation was written to the $4 \mathrm{~A}$ class inviting them to see our play. The pupils studied letter writing in the language lesson. They felt a need for this type of lesson because they were anxious for thelr letter to be perfectly done. A letter was written by each pupil of the class. Then these letters were written on the blackboard and corrections were made by the teacher and pupils. The best letter was chosen to be sent to the 4A. Below is the letter chosen:

$$
\begin{aligned}
& \text { Fingelhard School, } \\
& \text { March 15, } 1944
\end{aligned}
$$

Dear Friends:

The $4 B$ class has been studying about the people who live under the blazing sun. Would you like to know who they are? If so, come to our room next 
Friday, at 1 o'clock and you will find out. Let us know if you can come.

$$
\begin{aligned}
& \text { Sincerely, } \\
& 4 \text { B Class }
\end{aligned}
$$

b. Ridales

one of our most interesting lessons was the writing of riddles. These were planned during the language period. The following items were used in preparation for the riddles.

(I) Choose a topic.

(2) Select the thought to be told.

(3) Use a good sentence to tell each thought.

(4) Tell the thoughts in order.

(5) Keep to the point.

(The writer presents several of the riddles written by the pupils as evidence of their work.) The pupils read the riddles orally and the other pupils guessed the answers.

I have long legs and big feet. I can take giant steps over the hot sand in the desert. I have heavy eyebrows and thick eyelashes. I have tough lips and strong teeth to help me eat cactus and tough desert grass. My hump is my storehouse for food. I can live for several days on the fat in my hump. I can go for many days without water. I am sometimes called the "ship of the desert".

I am the largest bird in the world. I live on a desert. I have long legs and big feet like a camel. I can go without water for a long time. I am some times called a "camel bird". People of the desert hunt me beoause of my beautiful feathers. Ladies like to wear my feathers on their hats. 
I grow in hot, dry lands beacuse, like the camel, I can store away enough water to last a long time. I have thick, though, prickly leaves. I have my roots near the top of the ground. When it rains, my thirsty roots drink all the water they can reach. What am I?

I am a large basket. I fit on top of a camel. Women and children ride in me. I protect them from the sandstroms and the heat of the sun. I have ourtains all around my sides. What am I?

We ar a group of travelers on the desert. We start out early in the morning with our camels heavily laden with goods. At noon when the sun is hot, we stop and put up our tents to rest a fow hours. We ride until late at night. It is safer for us to travel in groups because robbers try to steal the things we wish to trade in the city. What am I?

I have thivk, tough, pricky leaves. I can store water for days. The leaves are hard and tough so the hot sun can not draw water from me. What am I?

I am the most important tree to the desert people. I gro near an oasis or spring. I like to have my feet in the water and my head in the fire. I have a long, tough, scaly trunk and no leaves except at the top. My leaves are wide and feather-like. Swoet golden dates also grow at the top of my branches. What am I?

c. Usage

One of the chief coneerns of the teacher is to develop the ability to express the results of their thinking in correct and effective spoken and written language. The teacher must see that the pupils have ideas to express, "just as the composer of music, anxious to express his ideas, in a musical score, must learn about the system of musical notation, so they, anxious to express their ideas in words, sentences, 
and paragraphs must learn the forms and principles 17

which govern the use of English". They must master through arill such mechanical matters as spelling, sentence structure, punctuation, and capitalization.

The following work in correct usage was developed during the language lessons.

1. A sentenoe always tells a complete thought. Pupils were given material to read on desert life. The bibliography may be used for this material. They discussed the paragraphs read and discovered that facts are best understood when they are told in sentences.

2. A sentence is a group of words that tell a complete thought. The teacher wrote groups of words on the board such as, many of the camels; traveled on again; or behind the caravan, etc. The children were to find these groups of words in the story read and tell which sentence each belonged. They were given words and told to use them in complete sentences. This was followed by groups of words to use in sentences.

3. The first word of a sentence begins with a capital letter. The last word of a sentence is followed by a correct punctuation mark.

17

Thonas, C.S., Paine, M. A., and Ensweiller, N.G., Thought and Expression, New York, Longman Breen and Company, 1939. 
The pupils felt a definite need for language lessons on correct usages. They wanted their oral and written reports as well as their dramatization to be as well done as possible. After the teacher had graded solne of their reports, she found they needed work on capitalization and punctuation. Comments given were, "I believe we all should work on improving our written work"; or "I don't know what kind of a mark to put at the end of my sentence". The teacher had many lessons on capitalization and punctuation. She found it very helpful to have the pupil read paragraphs orally and the other pupils to tell where a complete thought ends. The teacher explained to them the use of punctuation marks and when to use a capital.

3. Reading

A typical reading lesson is given in the first part of this chapter. The pupil had an opportunity to secure information from various sources. Individual silent reading of textbooks and library books, consisting of descriptive and factual, as well as narrative material was enjoyed by all pupils. Group reading of supplementary material preparatory to giving oral reports and the preparation of a dramatization was much in evidence. Much information was learned from 
which the pupils gained a deeper, enriched understanding of desert life. The children read orally interesting or entertaining parts of stories or descriptions to the class. This was a real audience situation, and provided an incentive for the poor reader to put forth a greater effort in his oral reading so that he would be well received by his group. The pupils were given training in how to locate information needed. other learnings listed below were developed by this study:

a. A knowledge of the location, purpose, and contents of the different parts of a book.

b. Use of the index of a book.

c. Use of glossary and dictionary.

d. How to handle a book with proper care.

e. How to skim through a book

4. Science

a. Simple experiments provided the first understanding of the desert elimate. The reading lesson provided the information about the effects of the desert on animal life.

The general effect of insufficient rainfall or moisture in a region was illustrated by an experiment performed in the classroom. A disoussion period followed 
the experiment.

(1) First the pupils planted seeds in two pots. They watered the seeds in one pot regularly but gave the seeds in the other pot no water.

(2) After observing that only the watered seeds sprouted, s discussion was held on the childrens' own gardening experiences and the importance of water to vegetation.

(3) The pupils then studied pictures of desert regions, contrasting the plant and animal life of the desert with those of their own cummunity.

b. In an effort to understand that the desert is not entirely barren the children learned about an oasis by answering the following questions:

(1) How do plants get water from underground drainage as well as from above? This was demonstrated by two potted plants, one of hich was set in a saucer of water and the other watered from above.

(2) What becomes of rain water?

Wells were given as evidence that some of the rain water sinks into the goound to form springs and wells.

(3) Where does the water come from to form an oasis?

Diagrems were made showlng layers of rock that carry water from the regions where there is much rainfall to spots in the desert, thus forming osses. 
c. How plants must be adapted to live on very small amounts of water and under intense sunshine was studled through the simple experiment of placing a cactus leaf in the sun beside a geranium leaf. The geranium leaf was found to wilt very quickly, whereas, the moisture holding cactus leaf survived for a considerable length of time.

\section{F. Activities}

1. Construction

Desert life offers numerous opportunities for interesting activities, particularly the representation of desert scences on the sandtable. The pupils were very anxious to depict the life of the Bedouins on a sandtable. Our first problem was to decide where we would have the scene. One child suggested the corner of our room. But other children objected to this place because of the windows near and this space would not afford ample room for a good background. Another ohild said he thought it would be better to use one of the large library tables and place it next to the partition that separates the classroom from the cloakroom. The partition would serve as a wall upon which the background could be tacked. All pupils were enthusiastic about this suggestion and readily agreed that this would be an ideal place for our desert seene. Our next problem was getting the sand. Several 
pupils volunteered to bring in the sand. A spirit of cooperation prevailed throughout the entire planning of our representation. The pupils discussed the different things to be shown and finally decided upon a desert camp showing the oasis, a tent, a spring, plants, a caravan arriving at the oasis, and the people. The background was include an outline of an oasis town with a caravan approaching the camp. After planning our soene, the pupils suggested that the class be divided into groups and have each group be responsible for a certain part. These groups were listed on the blackboard and a chairman was chosen for each group. The following groups were chosen; those to make the tent, another for animals, another the people, still other for the plants, spring, and the background. It was particularly interesting to the writer to see the wise choices the children made in choosing their chairman. In most instances the chairmen chosen by the pupils would have been the teacher's choice also. They seemed to want to place the pupil best suited for a particular group in that place. For example, the pupil chosen for the drawing of the animals was one of our best "artists". The one chosen to make the tent was the one who could cut out vell and do unusually good constructive work. In the discussions of plans, drawing of preliminary sketches, gathering of essential materials, and the appointment of committees, the students eagerly proceeded to work out their own 1deas. Much initiative was 
shown by all pupils, even by those who were usually timid or lacked initiative.

The next day sand and rocks were brought in by pupils. The desert was made with sand hills and rocks as the children had seen it in the pictures. The well was made of clay and stones and extended about three inches above the sand. To make the lake, the pupils decided to use a paint cup filled with water imbeded in the sand, and place palm trees and cactus plants around it. This brought up the question, "What shall we use for palm trees?" One pupil answered, "We could make them out of paper and stick them in the sand". "Yes, but I believe they would fall down", added another pupil. "We could use heavy straw board or branches from trees would be better." Finally the group decided to use strawboard for the trunks, and green construction paper for the leaves. In making the palm trees, the pupils experimented with the height of the trunks to get the relative size of the leaves, and some chiloren cut large leaves, about six inches long, medium-sized leaves, about three inches long, and small leaves, about one inch long. It was finally agreed to use the medium-sized leaves. The pupils realized that if the large leaves were used, they would be too large for the trubk of the tree. After placing the sand on the library table we realized it would be hard to keep the sand on the table because some had already been dropped on the floor. So the suggestion was 
made that folded strips of tagboard extending about two inches above the table's surface be thumb tacked to the table edge. This proved to be an excellent suggestion.

The committee that worked on the tent ran into several difficulties. At first they were going to use pegs stuck in the sand to hold up the tent. They soon discovered that it was very difficult to get the sticks to stand up. one pupil suggested using $s$ ahoe box and cutting it out and leaving the corners as a frame work. In order to make the top of the tent stand up in the middle, a large stick was put through the top of the shoe box. A piece of unbleached cotton was striped with colored chalk for the top and sides. A very attractive Bedouin tent adorned the sandtable. One pupil said he thought the tent should have two rooms one for the father and boys and the other for the mother and girls. Another child on the committee readily brought forth a piece of striped material he had been preparing for that purpose. One of the girls sewed the cloth in its proper place.

The camels, horses, and sheep were cut from heavy cardboard. These animals were colored with chalk or crayons; the sheep were covered on both sides with cotton batting making them very realistic indeed. One alert pupil said that he would like to make a litter on a carnel for the women and children to ride in. He set to work with a will and soon constructed a framework of strawboard covered with striped material for the litter. He glued this to the back of a camel to the delight 
of his classmates.

A churn was made from heavy cardboard painted to represent goatskin and fastened to three poles so that it could swing back and forth. This was placed in front of the tent.

The committee that worked on the people decided to use clothes pins to represent the Bedouins. They looke carefully at the pictures of the Bedouins and tried to find the difference between the dress and the headdress of the men and women. The heads of the clothes pins were painted brown to look as near like Bedouins as possible. Small pieces of cotten dipped in black paint were used for the beards of the men. Many scraps of material were brought to school to use for the clothing. The pupils had a very enjoyable time trying to match the colors that they thought should go together. Very often the boys would ask the help of the girls in draping the cloth on the clothespin. The boys were as eager to dress the dolls as the girls were. The material was either pinned or sewed on the clothespin. One doll was dressed in purple as the Sheik, and with his lance stood beside the camel at the head of the caravan.

A turban of bright colored cloth was draped on the head. Some clothespins were dressed as women and children. The fact that the committees worked together toward a definite end and observed the pictures of desert dress with the express purpose of dressing their clothespins exactly as the Bedouins in the 
pictures were dressed, made the work much more real than if they had simply heard about the dress of the people.

The background for the sandtable is described under the culminating activity of Art.

The sandtable described here is not the only way a scene may be represented. Below are given other suggestions that the teacher may want to use:

1. A large scene may be on the floor or in one corner of the room so that it would be large enough for the pupils actually to use. It may include a tent, palm trees, camels and poople. The tent and trees may be made in the same manner as described in the sandtable scene, but on a larger soale. People may be made from paper sacks. Take two sacks, a small one stuffed half full of cotton for the head, the end of this being put through a hole in the bottom of a much larger bag and fastened with paper fasteners. Rolls of paper may be used for arms. Pupils could bring in material and dolls may be dressed in the same fashion as the clothespin dolls described in the sandtable scene. Camels, sheep, and horses may be made from straw board on a larger scale. Cushions may be brought from home for the pupils to sit on. Children like to dress like the Bedouins. They could use old sheets, soarves, or bath robes, and turbans wrapped around their heads and play 
shoes would do for their feet.

Still another way to construct a scene is in individual boxes. Each child could get a hat box or large cake box which would stand on top of his desk and construct a desert scene in it. The top and one side may be taken out. The inside could be used for the scene. Each pupil could use his own ingenuity in planning his scene.

2. Preparation of Bedouin Food Another one of our interesting activities was our Bedouin Iunch. The group that worked on the food prepared for the whole class a Bedouin lunch. To be sure they consulted the teacher in preparation for the lunch. One of the pupils brought in a book that told how to make brown bread that was very much like Bedouin bread. Three of the girls on the group decided to meet at one of the girl's home and make the bread. The child's mother had told the teacher that she would supervise the bread making. The pupils made two loaves of bread but the teacher bought some brown bread from the store just to be sure there would be enough for the whole class. The pupil's mother sent us enough butter and cheese for the brown bread. The group realized that they would be unable to get camel's milk or goat's milk so they said we would have to use cow's milk from the lunch room. The arrangements were made with the supervisor of our lunch room to have the milk served 
in our room at the specified time. The committee wanted to have dates also, but they decided they could not afford to buy the dates themselves. The teacher offered the group the dollar they had won for having the largest attendance of mothers at the Parent Teacher Meeting. The childrens eyes sparkled when this suggestion was given. other contributions were made by the group and the teacher took the pupils in town to one of the fruit stores and purchased the dates. since our room at ample space at the front and sides for the children to sit down like the Bedouins do when they eat, it was suggested that we make it as near like a Bedouin lunch as possible, and all puplis sat down on the floor to eat their lunoh. Three pupils dressed like Bedouins and served the Iunch. Most of the pupils had their first taste of dates. They all agreed that the Bedouins' foods were very delicious. After the lunch some pupils told stories that Bedouins like to hear. After the stories were told the dramatization written by the pupils was presented.

3. Dramatization

A very simple lttle dramatization was presented by three committees for the entertainment of the class. It was so well received by the class and principal that we were asked to give it for other pupils on our floor. The writer

\section{8}

Smith, N.B., and Bayne, S.F., Distant Doorways, New York, Silver Burdett Company, p. 66-133 
is recording the dramatization as an aid to teachers in planning future programs and as a suggestion for an activity that is always enjoyed by the pupils.

The costumes for the play were very simple. The suit worn by Uncle Sam was made by one child's mother. It consisted of red cambric trousers stripped with one inch wide bands of white cambric. The coat was made of blue cambric with white stars of cardboard sewed on for buttons. One of the children made the hat of tag board. Around the hat band were pasted blue stars. On the crown of the hat were pasted red stripes about one inch wide.

The desert children were dressed in sheets draped around them with wide scarves for sashes. A white cloth was used for a turban. Two boys were dressed in striped bath robes and turbens. The American children wore their regular school clothes.

\section{Desert Party}

A dramatization written by the Fourth Grade pupils with the help of the teacher at the Victor H. Engelhard School. Charaoters

$\begin{array}{lll}\text { American children } & \text { Ruth } & \text { Sarah } \\ \text { Sally - Hostess } & \text { Jack } & \text { Henry } \\ \text { Jimmy - Host } & & \\ \text { Uncle Sam (in costume) } & & \end{array}$


Desert Boys

Omar

Alem

Ali
Desert Girls

Rahma

Gemila

Ada

Setting

Dining room at Jimmy and Sally's American home. A long table is set for dinner.

(Sally and Jimny are receiving guests. The boys and girls seat themselves, laughing and talking informally. Uncle Sam enters last.)

Sally - Boys and girls, I wish to present our very honorable guest in whose honor we are having this party our dear Uncle Sam.

- (All arise and applaud - followed by singing Amerioa.)

Uncle Sam-(bowing) You make me very happy indeed.

(All sit down together.)

Ruth - I know we are all honored to have Uncle Sam here. Jimmy - It is because of our inteest in the desert people that sally and I decided to have a party for our little desert friends whom we have been studying about.

Henry - I think it is a good thing to have the children from North Africa to meet in this friendly group. Sarah - If we are friends when we are children, we will grow up understanding one another better. What do you think about this, Uncle Sam? 
Unole Sam-Yes, I think you are quite right. You will learn to have more respect for other peoples of the world and to understand how our desert friends live.

Omar - Who knows, perhaps we may grow up to be ambassadors to the United States.

Rahma - Maybe, I will come to your country and study about your schools so I can help my people to become better citizens.

Jimmy - Uncle Sam, perhaps you would like to know more about the people these children represent.

Uncle Sam-I am always interested in learning more about friends all over the world.

Sally - First, I want you to meet Rahma. Come Rahma, and get acquainted with Unlce Sam. (Rahma comes forward and curtsies before Uncle Sam.) Rahma - I am very glad to know you, Uncle Sam. Uncle Sam-I am happy to see you and hear what you have to tell us about your country.

Rahma - I know you have heard of the Bedouins. I belong to that wandering tribe of people who roam from place to place searching for food and water. My father is Sheik Coman. He is leader of our caravan. He always wears a white robe thrown over his shoulder and carries a bright dagger in his sash. Most of the men in our tribe are desert herdamen. They raise sheep, goats, donkeys, and camels and sometimes a few horses. 
We live in tents because we must move often. When the flocks and herds eat all the grass in one place, we move on to another place where the grass is better. Hy brother omar will tell you about our homes.

Sally - Come Omar, and meet our dear Uncle Sam. (Omar comes forward and shakes hands with Uncle Sam.)

Omar - I am very happy to be here and to have a chance to tell you about our tent home. once I took a notion that I wanted to stay in the oasis town with my uncle, but after as few days there I soon changed my mind. I longed for the open desert and the peace and quiet of the starry nights. our tent is large and confortable. The roof and sides are made of cloth woven from wool, goat's hair, or camel's hair. It is held up by poles. Usually there are only three sides. One side away from the wind is left open. When the wind changes, the side walls are so that the open side is always away from the wind. Scattered about on the floor are several cushions on which we sit and sleep. A hole in the ground is our stove and fireplace. Nearby we keep several pots and pans for cooking. our food is stored in woolen bags. There are bags of rice, wheat, barley, and dried dates. There is nothing that cannot be packed up easily and losded on a camel. 
Jack - Your way of cooking reminds me of the way we cooked when we went on our last hike, Omar.

Omar - Yes, but you just cook that way when you go on a hike. Remember we cook this way day after day. My friend Gemila will tell you more about our food. (Gemila comes forward and curtsies before Uncle Sam.)

Gemila - I suppose you have been wondering where we Bedouins get our food. Most of us drink a great deal of milk. Bometimes it is almost the only food we have. We get the milk from goats, sheep and camels. Sometimes our fathers kill some of our animals for meat. We buy the rest of our food from the people of the oases. We buy such foods as wheat, barley, millet, rice, and dates. We pay for them with animals or with the things we get from our enimals such as, camel's hair, goat's hair, or wool.

Sally - How do the people on the oasis town live?

Gemila - Alem, wouldn't you like to tell our American friends about the oasis town? (Alem comes forward and shakes hands with Uncle Sam.)

Alem - I will tell you about the town called Murzuch. It is in the northern edge of the desert. All around the town are walls of mud. There are many gardens around the town. This means that you can get some good things to eat. You will also find enough water 
to wash your hands and face. You know, when we finish our meal in the desert we wash our hand s in the sand and save the water for drinking. Throughout the gardens of Murzuch are wells and irrigation ditches. Camels and donkeys are used to pull up the buckets of water for the ditches.

Sarah - Yes, I remember seeing a picture of a camel pulling up a bucket of water from a well in our geography.

Alem - I am glad that you have seen that picture. The camel walks down into a hollow, then it pulls on the rope that lifts a leather buoket from the well. This bucket is emptied into a ditch, and the camel backs up to the well again. I spoke of the gardens. Ada will tell you more about the food grown there. (Ada comes forward and curtsies before Unole Sam.)

Ada - The tallest plants in the gardens are the date palms. They are even taller than the walls. They make little shade becuase their tops are small. The sun shimes down through the tops to other plants beneath. other plants are fruit trees, such as apricot, orange, olive, pomegranate, peach, and fig trees. Beneath the fruit trees are grains and vegetables.

Rahma - Don't you believe, Ada, that these children and Uncle Sam would like to know about our schools?

Ada - I know they would, Rahma, you tell them about the one you went to in Murzuch. 
Rahma - Once I stayed with my aunt in Murzuch and I went to school for a while. The sohool, of course, is very different from your school. The teacher sits on the ground and the pupils sit around him in a circle. You learn to read and write in our language. I learned to add, subtract, nultiply, and divide. If you want to learn more you can go to school in a large city. There the schools are much larger and better. I didn't go to school at all while we were. traveling over the desert. My mother was my teacher. She taught me how to weave and how to make butter and cheese. Father taught my brothers how to get water from the well and how to tend sheep.

Ali - I would like to tell our friends about an interesting little oasis of Blima. Bilma is small, and there is not much water except the water in the lake. The lake water is salty like the water in the ocean. It cannot be used to make plants grow. But salt is gotten from this lake. It is poured into shallow tanks and then dried in the blazing sun. A crust of white salt is left in the tanks. People come many miles to Bilma to buy salt.

Henry - Speaking of salt, reminds of of the story of Daniel Boone going to the salt licks for salt and the Indians capturing him. 
Ali - Well, we don't heve to worry about Indians in our country. But we do have to be on the watchout for robbers. Sometimes the robbers steal our animals and food supply. The sand storms is another danger we have on the desert. But all of us are well trained in what to do if a sand storm comes up.

Uncle Sam-I am interested in hearing about our fighting forces who have won a great victory in your country. How did they get along living in such a different country than ours?

Ruth - Yes, Uncle Sam, we chilären have been reading some interesting stories of our soldiers in the desert country of North Africa. One story told about the hard time some soldiers had in finding their camp when they were lost from the other men. Wind causes ripples marks and ridges, and quickly covers up tracks. The surface hardens so that heavy mobile forces traveled off the few built roads. Clanking treads of tank runners tore up the desert floor and formed clouds of dust which choked the soldiers and machinery. Burning winds from the South blew the sand into clouds which rolled across the desert, stopping transportation.

Sarah - Yes, but I read where our boys learned quickly what to do when a sand storm came. They would wrap up 
thoroughly and the animals would crouch flat, waiting for the storm to pass.

Henry - Sarah, I read where the blazing sun on the desert made a white, hot light and the glare against which the soldiers' eyes needed to be protected.

Ali - Yes, you are right, Henry, the sun seems much hotter to people to who are not used to it as we are. our eyes are used to this glare and when it gets too hot we just pull our turban over our face - see like this. (Ali pulls his turban over his face.)

Rahma - We women and children ride in litters on camels and when it gets too hot we pull the heavy curtains around us.

Ruth - I found out that this blazing sun produces mirages in the form of cities, water, and palm trees, so real in appearance that it often fooled our armed forces.

Henry - We think we have hot weather in the summer, but I read that some of the battles were fought in a temperature around 135 degrees. But night in the African desert is always cool. When the temperature is 120 degrees by day, it may be 40 or 50 degrees by night. The soldiers just had to get used to this sudden change in temperature.

Sally - One article I read said that mechanized or camel convoys saw to it that our did not have to go with- 
out water. The troops had to be very careful about the kind of water they used because the wells may have been poisoned or infected.

Jimmy - When one of you desert children spoke about your tent home it reminded me of what I read in the paper about our soldiers' tents. It said that the tents of soldiers looked like a settlement of early Bible times. It also said that sometimes it took as many as twenty men to set up a tent against stinging sand and wind. When the soldiers were going to be in a place for any length of time, small cabins were built for the men.

Uncle Sam-But I can assure you that my armed fortes were always ready to meet any situations that faced them.

Sally - Well, Uncle Sam, I believe we have heard from all of our little desert friends. How did you like our party?

Uncle Sam-Sally, you have made me very happy indeed. It does my heart good to see you children taking so much interest in our desert friends. A toast to our good friends and world neighbors who live "under the blazing sun".

\section{All - Hurrah! Hurrah!}

(All join hands around the table and sing, "on the Desert Sand", page 71, Foresman, Second Book of Songs. Then as they arise to leave "The Star-Spangled Banner" is sung. 
4. Art

Shepherd and desert life afford a wealth of opportunity for drawing and cutting interesting and colorful pictures for illustration. One of the most delightful part of the unit was the preparation of the background for the sandtable scene. The pupils planned the background during the Art period. The suggestions made by the children were written on the blackboard. Such comments typical of the discussion were: "I think since we decided to have a camp scene on the sandtable that we should show part of an oasis town in our background". Another pupil agreed saying, "Yes, I think you are right, but let's be sure we have our sandtable scene and background connected in some way". Still another pupil said he thought it would be well to show a caravan in the background approaching the camp scene. After much discussion the group agreed to show an outline of an oasis town, a caravan of men and camels leaving the town and approaching the sandtable scene. Fach pupil of the group went to work and sketched in what he thought should be in the background. At the end of the period each member of the group came forward and explained his picture to the class. The children showed much thought and evaluation in judging the pictures to be enlarged for the background. The work of the pupils was entirely creative. There was no copy work whatsoever. After selecting the best pictures, the pupils set to work on the 
large drawing.: Colored chalk was chosen as a medium. These pupils had previously used paints for a large mural and they decided that they would like to try colored chalk. The scene when finished was indeed a piece of creative art. It was admired by all the classes of the school.

The remainder of the class drew pictures which were used to illustrate their oral reports. Such illustrations included the following topics:

The Ostrich

A Bedouin Tent

Sheep

A Caravan

Shearing Sheep
Bedouin People

Palm Trees

An Oasis

Preparing a Heal

At the Market

Such mediums as paints, colored chalk, crajons, and charcoal were used in the art work.

\section{G. Evaluation}

After the completion of the unit, Under the Blazing Sun, tests were given to check the progress of the group in ability to check information learned; to select main ideas; ability to follow directions; and to use correct language. Below are given some of the typical tests administered to the class. Many other tests may be devised by the teacher to test the results of the unit. The material that follows was mimeographed by the teacher and each pupil was given his individual sheet. 
1. To check information learned.

a. Directions: Read these parts of sentences carerully and conplete them in your ow words:

(1) on egroup of people who live on the desert are

(2) They have to move from place to place to find

(3) The Bedoutns make their home in

(4) The Bedouins olothes are made of

(5) A group of travelers and aninals moving across the desert is called

(6) Bedouins travel in groups because it is

(7) The foods that the Bedouins eat are

(3) The holy book of the Mohammedans is called the

(9) The leader of a Bedouin tribe is called the

(10) Bedouln wotien travel in

(11) Two great dangers of the desert are

and

(12) The animal that helps the Bedouin the most in his ways of living is

(13) A place where the people are called to prayer is called a

b. Directions: Write True or False after each sentence.

(1) The safest way to travel across the desert is in a caravan.

Wilson, H.E., and Others, Ways of Living in Many Lands, New York, American Book Company, 1937, p.90. 
(2) Caravans start early in the morning.

(3) Acaravan always stops at sunset.

(4) Camels like to carry heavy loads.

(5) Camels are the best animals to use in the desert.

(6) Water is carried in bags made of goatskin.

(7) A camel carries the tent home on his back.

(8) The Sheik rides on a horse at the head of the caravan.

(9) Riding a camel feols like riding a ship.

(10) The caravan stops at noon to rest.

(11) At night the desert stays warm.

(12) The men go to the city to rest.

(13) They trade wool and cheese for wheat and coffee.

(14) The homes in the city are like the desert homes.

(15) The desert is hot in the middle of the day.

(16) The desert people have plenty of water.

2. To select main topics.

a. Directions: Read this paragraph carefully and tell which group of words tells the main idea best. Oasis Gardens Palm Trees Watering Desert Crops

\section{0}

Simpson, M. E., and Adams, M. A., Growth in English, New York, Newson and Company, 1934, p. 45. 
Oasis gardens are not like our flower gardens but they are beautiful and useful as well. Feathery date palms grow in groves around a spring of water. Beneath their tall branches are little patches of alfalfa for the animals to eat. Vegetables are raised in the rich soil near the rougi trunks of the palm trees. The oasis dwellers water their gardens carefully. They grow fruit and vegetables to sell to the caravan travelers.

b. Directions: Here are some names for each part of this story. Choose the name that fits each part best and write it on the line above that part of the story. How Alem and Rahma Travel

What the Children Wear

A Tent Home

A Hot, Dry Land

What Alem's Father Does

What Rahma's Mother Does

Good Times

School on the Desert

Food on the Desert

Alem is a little boy who lives in a hot, dry land on the Sahara Desert. It is dry land because rain almost never falls there. It is hot because the sun shines hot in that part of the world.

Alem and Rahma, his sister, wear long loose clothes. 
Rahma likes a blue robe. Alem wears a white shirt and a bright striped coat. Turbans are worn to protect the head from the heat of the blazing sun. The children wear sandals on their feet. Sandals are the best shoes for a sandy land like the desert of the Sahara.

Alem's father is shepherd. He has a small flock of sheep and a few camels. He wanders from place to place to find green grass and water for his animals. When the sheep have eaten all the grass in one spot, they move on to another place. Alem helps his father take care of the sheep.

Rahma's mother weaves the wool of the sheep into rugs, shawls, and cloth. She bakes large, flat loaves of barley bread. She cooks sweet date cakes. She churns goat's milk in a skin bag. Rahma likes to help her mother weave and cook and churn.

Alem calls his home a "house of hair" because it is made of hair from their goata or camels. His home is a tent because his family moves so often that they must have a home which they can carry with them. They move often because the land is hot and dry with very little water. The Bedouins move to find food and water.

The children like to eat the sweet dates that grow around the springs in the desert. Alem thinks the large, flat loaf of bread that his mother bakes is the best bread of all. Rahma likes the thick, creamy camel's milk and the cheese which is made from goat's milk. Sometimes Alem catches a rabbit and brings it home for the evening meal. Then he gathers dried grass and bushes for their fire hole. When the meal is ready, he likes to dip his bread in the steaming pot of stew.

Sometimes the children go to school. The school is only a shed with palm leaves to keep out the blazing sun. 
The children sit on the floor of sand and read their lessons out loud. It is a noisy school with many children reading aloud at the same time. The teacher may weave or do some other work while the children are studying.

Alem and Rahma like to ride on a camel. When the camel kneels down, they climb up on the saddle. They hold on tightly when the big camel rises. They rock from side to side as the camel takes long steps aoross the desert. Sometimes when the sun is very hot, the children ride in a litter. If the sun gets too hot, the travelers stop and rest.

The children like to play games. They like to play leapfrog in the s\& $\mathrm{ld}$. They are not hurt if they fall down. They like to run races and to play tag as muoh as we do. The children like to sit around a fire in cool evenings and hear the old, old stories that their parents tell.

3. To follow directions. All of the tests given include this ability but the one given below is best illustrative of this ability.

a. Directions. Below are some words. Put $I$ in front of the words that tell about the cactus. Put $\underline{2}$ in front of the words that tell about the camel. Put $\underline{3}$ in front of the words that tell about the date palm. Put $\underline{4}$ in front of the words that tell about the ostrich. Put $\underline{5}$ in front of all other words. thick, tough, prickly leaves.

(2) goes faster than a camel. cluster of sweet golden dates.

(4) tough lips and strong teeth. 
(5) "house of hair".

(8) rough trunk.

(7) carries heavy loads.

(8) called a camel bird.

(9) storehouse in his hump. feather-like leaves. beautiful feathers. thirsty roots. heavy eyebrows. largest bird. goatskin bag. feet in the water.

(17) head in the fire. market place. hard, fat leaves.

(20) grows near a spring.

(21) leaves at the top.

(22) caravan. lays a large egg.

(24) mosque

(25) goes for days without water.

4. To use correct language.

a. Choosing sentences and correct punctuation marks. Select the sentences from the following groups of words. If it is a complete sentence, put a $\underline{c}$ at the end and the correct punctuation mark. 
(1) Rode at the head

(2) Soon they traveled on again

(3) Each morning the children went for water

(4) When the ostrich was seen

(5) Some men rode on donkeys

(6) As the caravan came to the oasis

(7) Was the sun hot on the desert

(8) Kept watch over the flocks at night

(9) The robbers were gone for that day

(10) What did you buy from the oasis

(11) On an oasis near the town

(12) See the blazing sun

(13) Hurry a sandstorm is coming

(14) We like date bread

(15) Protection from the stinging wind

b. Answering questions.

The teacher read the following questions and the pupils wrote down the enswers telling one complete thought about each question.

(1) Why are Bedouins wanderers?

(2) What is a caravan?

(3) How is the camel used?

(4) Why do the desert people use tents for their homes?

(5) What food do these people eat? 
c. Correcting paragraphs.

Copy the following paragraph in correct sentences. Be certain to put in the punctuation marks and capitals necessary.

the poople of the caravan were very hungry they had been traveling all day every one was glad to reach camp the women worked busily one of them broiled goat meat over the camp fire another milked the goats the bedouins sat on the soft sand to eat their dinner it tasted very good after their long hard day

d. Making sentences with groups of words. Below are groups of words, make sentences using these groups:

$\begin{array}{ll}\text { told stories } & \text { watched for robbers } \\ \text { tended sheep } & \text { studied the Koran } \\ \text { at the oasis } & \text { went to market } \\ \text { in the caravan } & \text { like to weave } \\ \text { at the well } & \text { rode in a litter }\end{array}$

e. Choosing paragraphs that keep to the point.

Here is a little test. It will help you to tell when sentences in a paragraph keep to the point. Read each paragraph carefully. Then follow these directions:

(1) Find the main idea of each paragraph.

(2) See if each sentence tells something about the main idea. 
(3) Copy the paragraph in which all the sentences keep to the point. Write it in correct paragraph form. Paragraph I

The oasis people use their friend, the camel, to help them water their crops. The camel is harnessed to a big wheel at the well. As he walks around and round he turns the wheel. The turning wheel lifts jars of water from the well and empties them into a trough. The water runs from the trough into the fields. Isn't this an easy way to water a desert garden?

\section{Paragraph II}

An oasis market is crowded and noisy. There the oasis dwellers bring fresh fruits and vegetables, hay, and barley loares. They know the caravan people will want to trade these things for their bundles of woolen thread and skins. Their camels carried them across the desert. Fach one calls out in a loud voice as he tries to make the best bargain.

Not the least gratifying of the outcomes of the unit was the evidence of growth among all pupils in appreciation of other peoples of the world as well as more appreciation for the rights of each other. A keener sense of cooperation among the class was evident. Finally the unit justified itself in the enfoyment it afforded every pupil of the class. 
CHAPTER IV TEACHING THE UNIT (Continued)

SOURCE MATHRIAL FOR THE TEACHER 
CHAPTER IV TEACHING THE UNIT (Continued)

SOURCE MATERIAI FOR THE TEACHER

The following subject matter is given for the teacher's convenience. This information was covered during oral discussions, reading lessons, and geography lessons.

\section{A. Anima 1s}

1. Camel

The Bedouins best friend is the camel. He is the animal best suited to desert life. He can travel without water for two or three days at a time. He drinks a great deal before starting and stores the water away in his body. He also eats a great deal and a hump of fat rises on his back. After many days of travel with very little food the hump is no longer firm.

The eyes of the camel are protected by heavy overhanging brows and thick eyelids with hair on them. Those help to protect his, eyes from the blazing light of the sun as well as from the sand. When a sandstorm comes, he kneels down, closes his eyes, and partly closes the long slits that are his nostrils, so that he does not breathe the sand. His mouth is hard inside so that he can eat the thorny desert bushes without any trouble. His lips are covered with thick,

\section{2}

Petersham, M., and M., The Story Book of Transportation, Chicago, Illnois, The John C, Winston Company, 1933, 
coarse hair which protects them.

Hach of the camel's feet has two toes joined by a pad. The pad spreads out when he walks so that his feet do not sink deep into the sand. The tough pad protects his feet from the burning sands and sharp stones. His knee joints also have natural pads. His long legs are very strong and with them he can take giant strides of six feet or more over the sand. The camel does not walk like other animals. He lifts both feet on the same side at one time. The rider is pitched from one side to another. If you were riding a camel for the first time, you might get seasick in this "ship of the desert".

Some camels are riding camels; others are baggage camels. When they are to be loaded or ridden, they get down on the sand. After the signal is given, they get up and start off. The riders show them which way to go by tapping their necks gently with a stick. Riding camels can easily travel fifty miles a day. A baggage camel can make about twenty-five miles a day if he is well loaded.

2. Ostrich

The largest bird in the world lives in the desert. This large bird of the sandy land is the ostrich. An 
ostrich has long legs and big feet like the camel. The ostrich can go for a long time without water and will eat almost anything it can find. It can run faster than a horse. Sometimes ostriches are called "camel birds". People of the desert hunt the ostrich because of the beautiful feathers in its wings and tail. Ostrich feathers can be sold or traded for things the desert people need.

3. Food

The Bedouins do not have so many foods to choose from as we have. They must eat the foods which they find on the desert.

1. On the desert

Host of the meat that the Bedouins eat must be traded for in the village, because wheat grows only around the oasis. The children help their mother grind the wheat between two stones. The bread is made from coarse flour and water kneaded into dough. The flattened dough is laid on part of the ashes, then it is covered with the rest of the ashes and is done in about fifteen minutes. The ashes are brushed off; it is 23

English, M., and Alexander, T., Wide Windows, New York, Johnson Publishing Company, 1935, p. 62.

24 McComnell, W. R., Living in Different Lands, New York, Rand WeNally and Company, 1938, p. 78 . 
broken into pieces, and divided among the family. The bread is often used for a plate and is eaten last. Sometimes the wheat or barley is cooked as a poriidge.

The people like fresh sweet dates dipped in butter, little cakes "fried in oil and dipped in honey", and locust wasted in the hot coals.

They get milk from the camel and the goat. As the milk does not stay fresh very long, they have learned to drink it when it is sour or to eat it as curds and whey. The milk is churned in a goatskin bag by rolling it over and over on the knee. Sometimes the leather churn is hung on sticks and shaken to and fro to make butter. Much of the milk is made into cheese.

The men and boys hunt small animals of the desert for meat. They often bring back hares, gazelles, and even lizards for the evening meal. When game is scarce they kill one of their sheep or goats. They like mutton stew and roast kid. The flesh of the camel is good to eat, but they do not kill the camel unless he is too old to work.

Dates are an important food on the desert. These are supplied from the oasis town. Dates are eaten 25

Ibid., p. 79. 
dried or fresh. Sometimes they are scrambled with eggs. The large bud of the date palm is called the date cabbage and is cooked as a vegetable.

The father always makes the coffee. The green coffee beans are roa'sted and pounded for brewing. Sweetsmelling herbs and spices are mixed with the coffee to give it a better flavor. The desert people were among the first people to begin drinking coffee, and it is still their farorite drink.

Tea is another drink liked very much in the desert home. Bedouins make their tea in earthen pots. Sometimes mint and spices are added. The sugar is boiled in the tea and it is not ready to drink until it is very sweet.

The Bedouins' kitchen is in front of the tent. Since rain almost never falls, an out door kitchen is very convenient. Dried shrubs and thorny plants are gathered for the fire.

First the men eat their supper. They sit on rugs and cross their legs. They eat chunks of meat with their fingers. They pass a bowl of water from one to another until all have had a drink. When the men finish eating, the women and children sit down for their supper. After supper they clean their hands by rubbing them on the sand. They save the water for drinking. 
2. On an oasis

The food on an oasis is more plentiful. In the towns are found tiny gardens where all kinds of vegetables are grown - carrots, beans, lettuce, and ll the regetables which we have at home. Apples, peaches, oranges, lemons, apricots, figs, pomegranates, grapes, and muskmelons are also grown here. Small wheat fields and rice fields are found in some parts. In order to keep back the sand each garden is screened round with a hedge of dried palm leaves; and each has to be irrigated by water drawn from a nearby well. The water is drawn from the well in skin buckets by a camel that walks backward and forward raising and lowering the bucket by means of a rope.

A very common tree in an oasis is the date palm. The boys climb up and get bunches of the dates. The date palm has a tall bare trunk, at the top of which are feather shaped green Leaves. Under the leaves, protected from the sun, are great clusters of dates, each cluster eighing from fifteen to thirty pounds. Dates are eaten fresh from the tree or dried. The dried dates are sometimes pressed into hugh cakes which can be easily transported on camels. The date palm is valuable not only for its eruit, but also for its wood, which is used as fuel and as lumber, and for its leaves, which make baskets, mats, and other ser- 
viceable articles.

C. Good Times

The Bedouin children do not have as much time as our children do to play, but many of their games are very much like ours. They also have many games that we have not heard of. During the hot part of the day they play quiet games. They play jackstraws with date seeds. They play marbles by rolling them into holes in the sand. Dominoes is one of their favorite games. The boys like to play juggling. In this game they try to see how many thing they can throw up and keep going at one time in the air.

Sometimes the children blacken their faces with charcoal and play that they are fierce men from a far country. They fasten pieces of wool to their chins for beards. They talk in a queer language.

They like to play games that will make them good runners. If they are swift runners, they can catch the camels that break away. When it is cool, the boys play these running and racing games. They play LeapFrog, Puss-in-the-Corner, and Blind Man's Buff. Another of their favorites is Tied Donkey. One boy is tied to a peg and the other boys try to hit him with their knotted head cloths. The boy at the peg tries to catch the others. If he does, the one who is caught must 
take his place.

D. Homes

The Bedouins of the desert do not have any settled home. They are always moving from place to place to find better food for themselves.

1. Tents

The tents are spun and woven from goat's hair or camel's hair. They call this kind of house "house of hair". It is a comfortable home because the thick covering is a protection against the heat of the sun and the wind of the storms. It is also waterproof in case of a rain on the desert. The tent is long and low and narrow. The top is almost flat except where it is caught up on the poles which hold it up. It is so strong that many bunches of dates may be dried on it at one time. Poles are driven in the sand to form the sides of the tent and some poles are put in the center to hold the cloth up. The roof is fastened with ropes to the poles and to pegs set in the sand at a little distance from the tent. The cloth for the back wall is put in place last and made secure in the same way as the roof.

There is very little furniture in the home. The

26

Freeman, F.M., and Johnson, E.M., Child-Story Readers, New York, Lyons and Carnahan Publishing Company, 1938, p. 119. 
family has to move so often that they do not like to carry many things about with them. The tent and all its furnishings can be carried on the back of a camel. In almost every tent there are a copper kettle for cooking, a wooden bowl for mixing, and brass eating trays. There are goatskin bags and earthen jars for water. often there are woven baskets for storing grain or food. In the day time, they spread woven rugs, mats, and blankets on the ground to sit on. When the air cools at night, they are used for beds and covering.

There are usually two rooms in the tent. A curtain is stretched in the middle to divide the house into its two parts. The best room is for the men. In it are the softest camel's hair cushion and the best rugs. The other room is for the mother and children. There are stored the kettles, food, water bags, saddles, clothes, and blankets.

2. Oasis town

The homes in the oasis tow are different from the desert home. These homes are small and made of blocks 28

of clay. The roofs are very flat. The house is

27

Wilson, H.E., and Wilson, F.H., Ways of Living in Many Lands, New York, American Book Company, 1937, p. 62 . 28

$$
\text { Ibid., p. } 75 .
$$


shady and cool. The walls are usually whitewashed inside and out. There is no furniture in the guest room, but there are many cushions. There is a large clay wall around the outside of the houses.

F. Land of Sahara Desert.

The Sahara, most famous of all deserts, is located in northern Africa. It continues across the Red Sea, into Asia, becoming there the Arabian Desert. There is probably no spot on the face of the earth where it never rains, but there are many sedtions where no rain falls for weeks, even months, at a time. Those portions of the earth's surface where the annual rainfall is ten inches or less are classed as arid or desert regions. Desert areas are closed basins walled off from the sea by mountain ranges which serve as barriers to shut out the moisture bringing clouds. These lands may be below sea level. Rain clouds approaching such a region are met by its mountain barriers, so that what rain does come into the desert falls largely near its edges. This rain either evaporates almost at once in the dry air and under the fierce rays of the sun, or soaks into the ground. USually in the spring a desert has a short rainy season, when flowers and vegetables grow up. But soon the moisture is gone and the plants die. It is not true that deserts have no rivers. They do have rivers, but 
the river beds are usually dry for much of the year. The temperature on a desert varies greatly. The thermometer may register over a hundred degrees by day and then fall below the freezing point at night. This is because of the general absence of clouds, since moisture is neded to keep the earth warm after the sun sets.

Desert soil is very salty. Salt is one of the principal products of desert regions. In Bilma is found a salt lake. It cannot be used to make plants grow. In fact, it is so salty that people make salt from it. over the desert is a constant movement of sand and dust, which drifts in ridges, changing like ocean waves. The wind lifts this sand over the waves or dunes as far as the edge of the desert. Tracks are quickly covered by the blowing sand. When a strong wind blows, great dust clouds blow across the desert. Sometimes there will be huge pillars of sand sweeping over the land. Deserts are not all sand, as many people believe. In places there are hills, even mountains. Rocks, gravel, and pebbles are plentiful. Some parts contain beds of clay. In the lowest parts water is found. Fertile places and lakes, often salt lakes occur, and well, water holes, and springs furnish water for man and beast.

29

McConnell, W. R., Living in Different Lands, New York, Rand McNaliy and Company, 1938, p. 80 . 
F. Occupation

1. Weaving

One of the occupations of the desert people is weaving. People living in tows weave in the houses in winter and the Bedouins who wander from place to place on the desert follow their flocks of sheep into the pastures and spin and weare while they watch them. Men and women, boys and girls in the town and out on the barren stretches weave beautiful rugs and robes. The sheep are sheared in the spring, the wool is washed, carded, and then spun into yarn or on wooden spindles. It is dyed in beautiful colors of red, blue, green and yellow. Then this yarn is woven into rugs and cloth. We use the rugs that they weare in our homes.

\section{Sheep raising}

Many of the Bedouins are shepherds. They have small flocks of sheep and some camels. These people wander from place to place to find water and green grass for their flocks. When the sheep have eaten all the grass in one spot, they move onto another place.

3. Shopkeepers

In the oasis town is found the market square. All around the square are crowded the queerest little shops.

\section{0}

Comfort, M.H. , Peter and Nancy in Africa, New York, Beckley-Cardy Company, 1935, p. 236 . 
The shopkeepers who have the same kind of goods to sell gather their booths together along the same narrow streets. Some of the streets have roofs over them. There is a Street of Sandals, a Street of Perfumes, a Street of Rugs, and many other queer little streets. one is a little street filled with shops where you can buy bright colored cotton cloth, many colored sashes, and soft silk veils.

In some of the booths, food is sold, such as, fish, peppers, fried in oil, figs, peaches, and apricots.

G. People.

The people of the Sahara Desert are really of the white race, but years of living in the open under the 31 blazing sun have made their people very dark. Their skin is brown, eyes are deep brown or black, and their hair is very black. Most of the men wear a beard.

The women and girls wear a loose robe. Around their head is a kerchlef of cotton, usually colored blue. The women do not like to have anyone look at them when out in the public. They cover their faces with veils when other people pass by. The Sheik's wife wears a sort of shapeless garment over yellow trousers, with a bright colored scarf around her head. The women are very fond of jewelry, beaten silver, bracelets, and

31

Wilson, H. E., and others, Ways of Living in Many Lands, New York, American Book Company, 1957, p. $5 \overline{1}$. 
anklets, and beads. Sometimes their clothes are of colored silk, embroidered in gold.

For the cool nights they make woolen cloaks from the hair of camels, goats, and sheep.

The men and boys usually wear a striped coat called a burmoose. Their long white shirt is called a tunic. Around the tunic they fasten a belt made of leather. Their white cloth turban is held in place by two ropes of camel's hair. It is folded so that a part of it can be drawn over his eyes if the sun is too bright. The end of the turban covers the shoulders and can be 32 drawn over the face if there is a sand storm.

On their feet they wear leather sandals made from the skins of the animals. At times they go barefoot, especially the servants and the children.

H. Plants

Many parts of a desert can support no growing thing, but other regions have some plent life. Every plant which survives must adapt itself to an arid condition, and develop some way of getting and keeping water. The cactus plant can grow well in hot, dry lands because, like the camel, it can store away enough water to last for a long time. Its thick leathery branches

32

McConnell, W.R., Living in Different Lands, Chicago, Illinois, Rand McNally and Company, 1938, p. 74. 
are able to store up moisture and save it for dry periods. The leaves are thick, because they must have a place to store water. The leaves are hard and tough so that the hot sun cannot draw the water from them. The cactus plant has many roots near the top of the ground. When it rains, these thirsty, greody roots drink all the water within reach. The plant stores the water in its hard, fat leaves, and will not need water for a long time.

Other desert plants support life by sending long roots deep down into the earth until they have reached the zone of ground water. Roots of desert trees have been found more than one hundred feet long. Most desert plants have an usually large number of branching roots in proportion to the size of the plant.

other adaptations of plants to desert conditions are a thick outer skin to protect the plant from the hot sun; and hairs, spines, thorns, or spongy tissue for storing water. Certain plants will grow only in a salty soil, both of which are found in the desert. Another reason why desert plants keep alive is that there is no crowding. Fach plant can absorb all the moisture there is in the ground near its roots.

I. Schools

It is hard for the Bedouins to have schools when 
they move so often. $\frac{0 n l y}{33}$ the town and oasis cities can have real schools. But often in the Bedouin village there is a school that is sometimes just a shed made of palm leaves to keep off the sun. The fathers want their sons to learn to read and write and to be able to trade and count money. They learn to read the Koran, which is their Bible. They not only read the Koran, but they learn it by heart. Their books are in Arabic and are read from back to front and from top to bottom. of course their language is not like ours. lifost speak Arabic. Very few Bedouin girls go to school. Their fathers think there is no need for them to learn to read. Some little girls in the cities near the desert go to school.

\section{J. Travel.}

Bedouins are always moving from place to place to find better food for their animals and water for themselves. When the Bedouins wish to go to an oasis city to trade their wool and cheese, the family joins a camel caravan. A caravan is a group of travelers. On the desert, travel in a caravan is safer tha travel alone, for robbers try to steal the things that are to be traded in the city. The caravan starts early in the

33

Ibid., p. 87 . 
morning. The "houses of hair" are taken down and loaded on the back of camels. Women fill the goat skin water bags and hang them on the camel"s back. Camels do not like to have to carry such loads. They groan and even cry as they are being loaded, but the camel is the best animal to carry men and packs across the desert. The sheik or leader rides on his fast black horse at the front of the caravan. The mother and daughters ride on camels. Sometimes they ride in a litter. A litter is like a large basket covered with heavy material of camel's hair. If a sandstorm comes up, the women can pull the heavy material around them and thus keep out the sand. Often a desert caravan may be caught in a sand storm. Strong winds of the desert blow the sand in great clouds. The air may be so full of sand that the travelers cannot breathe. They pull the ends of their turbans in front of their faces. When the storm is a bad one, they stop the camels and have them kneel in the sand. Then the travelers lie down beside the camels until the storm is over.

At noon when the sun is hot, the caravan stops and the women put up the tents to rest a few hours. When the travelers begin their journey again, they ride until late at night. Riding under the stars is much more 
pleasant than riding under the blazing sun. At night the desert is so cool that travelers put on more coats to keep warm. Perhaps this may go on for a week. In time they will reach water and grass. Here they will settle down for a while, but before long the grass or the water will be gone again. This means another move and another journey, but the Bedouins do not mind that. They would not like to live in one place as we do. To them all the packing and traveling is a natural thing. No one could live on a desert in any other way. To them the desert is home - the only home they know anything about. 


\section{CHAPTER $\quad \underline{V}$}

EVALUATION OF THE UNIT

FRON THE STANDPOINT OF THE TEACHER 


\section{CHAPTER $\underline{V}$ \\ EVALUATION OF THE UNIT}

FROM THE STANDPOINT OF THE TEACHER

Through the groups' acquaintance with the Bedouin they all had a greater respect for the desert people, having noticed their ability to adapt themselves to their invironment, their cooperation with others, their hospitality, and their patience and cheerfulness. Such characteristics seemed to be reflected in the childrens' attitudes as they carried out the varied activities.

The writer, on the alert for evidences of improvement, noted the significance of such remarks as, "I certainly do appreciate my home more than I used to. Just think if I were a little Bedouin girl I would always be moving", or "Now I am more willing to share what I have with others. Because if the desert people will give a weary traveller their last drop of water, I know I can be more unselfish than I have been", or "Let's all be more friendly to our new classmates. I noticed that some of us have not been as friendly as we might be to James who came in our room last week. The Bedouins have certainly taught me the meaning of cheerfulness and friendliness". Remarks such as these are surely evidence that the study just completed has done something tangible for the pupils that is functioning in their everyday lize. Furthermore, it is pleasing to the teacher that many of her 
plans and purposes have been realized.

The group plan used in the working out of the unit proved to be of considerable value, not only in the success of the unit, but to the individual pupil. The child working in a small group is afforded epportunity to initiate and to execute his own ideas, and that he availed himself of the opportunity in this case is evidenced by inany of the outcomes. Much initiative was shown by the shy or slower children who ordinarily were unresponsive.

one of the most gratifying outcomes was the stimulation of independent reading. Pupils were anxious to read all the available material provided by the teacher and the nearby libraries. They were eager to share the material read with their classmates. The old stereotype book reports were placed in the background. The pupils volunteered their information in a most unusual manner for fourth graders. Such comments as, "Have you read, The Story of Ali and Hassan? If not don't fail to read it, because I know you'll enjoy the part about the sand storn"; or "If you like animals stories, you will be sure to enjoy the book, About Camels"; or "I think the book, Ways of Iiving, gives more information about the Bedouins than any I have read".

The pupils' comprehension in reading was improved greatly. The following abilities are noteworthy to mention in which great improvement was shown: 
1. Ability to gather material on a given topic

2. Ability to form an opinion

3. Ability to verify a statenent

4. Ability to draw a conclusion

5. Ability to follow instructions

Along with the improvement in comprehension may be mentioned the increased abilty to locate information:

1. A knowledge of the location, purpose, and contents of the different parts of a book.

2. Use of the index of a book.

3. Use of table of contents.

4. Use of dictionary and glossary.

5. Use of maps.

6. How to handle a book correctly.

Each group was very cooperative with each other. If one group working on a given topic found material that could not be used in their report, they would immediately give it to the group that could make use of the information. As one member of the class called it, "Give and take". "I have some stories on your topic that you could use, and you have some pictures on my subject that I would like to have, so we just, give and take". There was always a spirit of helpfulness, earnestness, and friendliness existing throughout the whole study. Certain members, for example, assisted in mounting pictures; others in arranging bulletin boards; still others, chosen for thier talent in drawing or construc- 
tion work, acted as artists in making the pictures and in preparing the sandtable ene.

The group that was most talented in dramatics wrote and gave the dramatization described in Chapter IV. This ability involved instruction and guidance on the part of the teacher, and considerable reading on the part of the pupils. Leadership and cooperation were developed among the pupils In planning for and putting on the playlet. Various phases of the work were chosen by the children best adapted to their execution, and all worked together in unity, each showing a willingness to share and assume responsibilities. The pupils showed creative ability in writing the play and in drawing the background for the performance.

In looking over the entire unit the teacher not only sees the numerous desirable outcomes, as herein stated, but also some of the opportunities that have been overlooked. The writer feels that probably the most noticeable activity not listed is in the realm of visual education. To be sure the teacher has included pictures and stereoptican views in this unit of work, but education today is looking toward slides and films as important factors in visual education. It is hoped that the next time this unit is taught that slides and films will be arailable to the teacher.

This unit may be extended to include a study of other deserts of the world. A comparison may be made with the 
Sahara Desert.

A further study of the United States Army in North Africa may be made. If possible the teacher could ask an ex-soldier from this region to speak to the group about his encounters and his way of living while fighting the enemy on the desert.

This outline and activities of this unit as herein described are not to be regarded as arbitrary, but they may be adjusted to any group of pupils at the age and grade level chosen. 
BIBIIOGRAPHY 


\section{BIBLIOGRAPHY}

\section{A. BOOKS}

Berkson, J.B., Education Faces the Future, New York, Harper and Brothers, Publishers, 1943.

Caswell, H.I., and Campbell, D.S., Curriculum Development, New York, American Book Company, 1935, p.400-446.

California State Curriculum Commission, Teachers' Guide to Child Development in the Intermediate Grades, Sacramento, California, California State Department of झducation, 1936.

Gwynn, J.M., Curriculum Principles and Social Trends, New York, The MacMillan Company, 1943, p.166-294.

Harap, H., An Experience Curriculum, Washington, D.C., National Council of English Teachers, 1941, p.105-109.

Hughes, R.0., "Some Basic Considerations of Social Studies," National Council for the Social Studies, Sixth Year Book, Philadelphia, McKinley Publishing Company, 1936, p.31-32.

Jones, A.J., and others, Principles of Unit Construction, New York, McGraw - Hill Book Company, 1939, p.1-131.

Leonard, J.P., and Eurich, A.C., An Evaluation of Modern Education, New York, D. Appleton-Century Company, 1942. 
Moore, C.B., and Wilcox, I. A., Teaching of Geography, New York, American Book Company, 1932.

Soclety's Committee on Teaching of Geography, The ThirtySecond Yearbook, Bloomington, Illinols, Public School Publishing Company, 1933, p. 201-264.

Storm, G. E., The Social Studies in the Primary Grades, New York, Lyons and Carnahan, 1931.

Thomas, C.S., Paine, M.A., and Ensweiller, N.G., Thought and Expression, New York, Longman Green and Company, 1939.

Tiegs, E. W. , The Management of Learning in the Elementary Schools, New York, Longman Green and Company, 1937.

Wesley, E.B., "The Nature and Functions of the Social Studies in the Elementary School", National Council for the Social Studies, Twelfth Year Book, Menaska, Wisconsin, George Banta Publishing Company, 1941. 
B. MAGAZINES

Review of Educational Research, XII, June, 1942.

Ross, C., "The Impact of War on the Social Studies", The Social Studies, XXXV, 3, March, 1944, p.116-120.

\section{c. PAMPHLETS}

Wichener, J.R., and Long, H.M., The Unit in the Social Studies, Cambridge, Massachusetts, Graduate School of Education, 1940, Harvard University.

Quillen, I.J., Using A Resource Unit, Washington, D.C., National Council for the Social Studies, 1942, National Education Association. 